The Vanadiferous Zone of the Phosphoria Formation in Western Wyoming and Southeastern Idaho

U.S. GEOLOGICAL SURVEY PROFESSIONAL PAPER 1465 


\title{
The Vanadiferous Zone of the Phosphoria Formation in Western Wyoming and Southeastern Idaho
}

\author{
By V.E. McKELVEY, J.D. STROBELL, JR., and A.L. SLAUGHTER
}

U.S. GEOLOGICAL SURVEY PROFESIONAL PAPER 1465

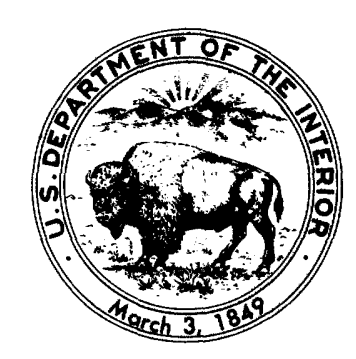




\section{DEPARTMENT OF THE INTERIOR \\ DONALD PAUL HODEL, Secretary}

\section{U.S. GEOLOGICAL SURVEY}

Dallas L. Peck, Director

\section{Library of Congress Cataloging-in-Publication Data}

McKelvey, V. E. (Vincent Ellis), 1916-

The vanadiferous zone of the Phosphoria Formation in western Wyoming and southeastern Idaho.

(U.S. Geological Survey professional paper ; 1465)

Bibliography: p.

Supt. of Docs. no.: I. 19.16:1465

1. Vanadium ores-Wyoming. 2. Vanadium ores-Idaho. 3. Phosphoria Formation. 4. Geology, Stratigraphic-Permian. I. Strobell, J. D. II. Slaughter, Archibald Logan, 1907- . III. Title. IV. Series:

Geological Survey professional paper ; 1465.

QE390.2.V36M35 $1986 \quad 553.4^{\prime} 626^{\prime} 09787 \quad 86-607918$

For sale by the Books and Open-File Reports Section, U.S. Geological Survey, Federal Center, Box 25425, Denver, CO 80225 


\section{CONTENTS}

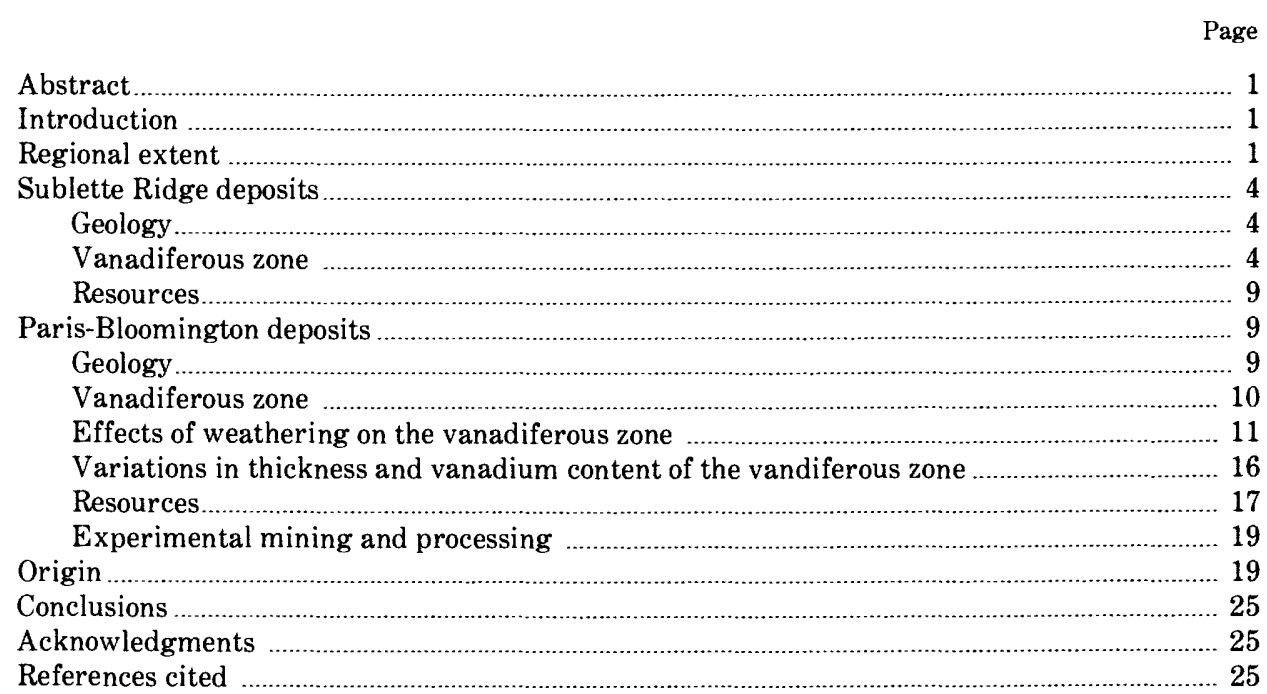

\section{ILLUSTRATIONS}

Plate 1. Profile of the vanadiferous zone outcrop at Sublette Ridge, Wyoming, showing the $\mathrm{V}_{2} \mathrm{O}_{5}$ content and the thickness of the zone at sampled localities

2. Detailed stratigraphic sections showing the distribution of vanadium within the vanadiferous zone at Sublette Ridge, Wyoming

Figures 1-3. Maps showing:

1. Approximate areal extent of the vanadiferous zone in the upper part of the Meade Peak Member of the Phosphoria Formation.

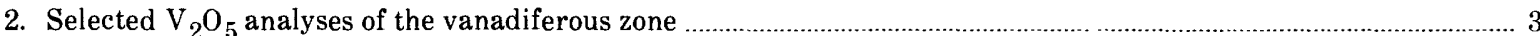

3. Average concentrations of organic C, P, V, and Ag in the Meade Peak Member of the Phosphoria Formation.

4. Graphs showing variation of nitrate, phosphate, $\mathrm{Cd}, \mathrm{Ni}$, and $\mathrm{Zn}$ in seawater with depth in the North Pacific Ocean at $32^{\circ} 41.0^{\prime}$ N., $144^{\circ} 59.5^{\prime} \mathrm{W}$ 


\section{TABLES}

Page

TABLE 1. Partial chemical analyses of the vanadiferous zone at Sublette Ridge, Wyo.

2. Chemical analyses of the vanadiferous zone and adjacent limestones at Coal Canyon, Wyo...................................................... 7

3. Minor elements in two beds of the vanadiferous zone at Coal Canyon, Wyo........................................................................ 7

4. Analyses of selected constituents of the vanadiferous zone at Coal Canyon, Wyo................................................................... 8

5. Selected electron microprobe analyses of semifusinite areas in sample VEM $42-47$ from the vanadiferous zone of the Meade Peak Member of the Phosphoria Formation at Coal Canyon, Wyo. …............................................... 9

6. Average thicknesses and $\mathrm{V}_{2} \mathrm{O}_{5}$ contents of the beds of the vanadiferous zone, based on all available samples ....................... 10

7. Partial composition of the vanadiferous zone and adjacent beds in the Paris-Bloomington area, Idaho .................................. 12

8. Partial chemical analyses of the vanadiferous beds in the Paris-Bloomington area, Idaho (U.S. Bureau of Mines) ................. 13

9. Partial chemical analyses of vanadiferous beds in the Paris-Bloomington area, Idaho (Anaconda Copper Mining Co.)......... 13

10. Analyses of samples from the vanadiferous zone at Bloomington Canyon, Idaho...

11. Estimates of minor-element abundances in the vanadiferous zone at Bloomington Canyon, Idaho, in comparison with their average concentrations in continental crust

12. Comparison of the thicknesses and $\mathrm{V}_{2} \mathrm{O}_{5}$ contents of partly leached, enriched, and unenriched rocks of the vanadiferous zone in the Paris-Bloomington area, Idaho

13. Comparison of the thicknesses and vanadium contents of the vanadiferous beds on the normal and overturned limbs of the Paris syncline, Idaho

14. Effect of lenses on the unaltered vanadiferous zone in the Consolidated mine, Paris-Bloomington area, Idaho ................... 17

15. Range in thickness and grade of the vanadiferous zone in the Paris-Bloomington area, Idaho ............................................... 17

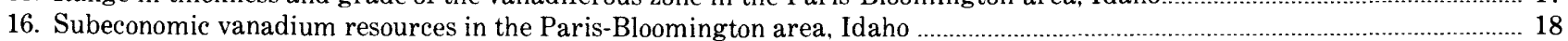

17. Some trace metals in seawater in comparison with their concentrations in black shales ....................................................... 22 


\title{
THE VANADIFEROUS ZONE OF THE PHOSPHORIA FORMATION IN WESTERN WYOMING AND SOUTHEASTERN IDAHO
}

\author{
By V.E. McKelvey, J.D. Strobell, JR., and A.L. Slaughter
}

\begin{abstract}
A black shale in the upper part of the Meade Peak Member of the Permian Phosphoria Formation contains an average of 0.8 to 0.9 percent $\mathrm{V}_{2} \mathrm{O}_{5}$ or more over a large area in western Wyoming and southeastern Idaho. In 1942 and 1943, this vanadiferous zone was sampled at numerous localities in the region by the U.S. Geological Survey, the Wyodak Coal and Manufacturing Co., and the U.S. Bureau of Mines.

At Sublette Ridge, $1 \mathrm{mi}$ east of the Idaho State line in Lincoln County, Wyoming, the vanadiferous zone lies about $50 \mathrm{ft}$ below the top of the Meade Peak Member in the nearly vertical eastern limb of a north-striking anticline. The full thickness of the vanadiferous zone in the explored part of Sublette Ridge contains about 1.9 million tons of indicated subeconomic resources above drainage level. The richer upper part contains about 1.35 million tons. In the Paris-Bloomington area of Bear Lake County, Idaho, in the eastern foothills of the Bear River Range about $1 \mathrm{mi}$ west of the towns of Paris and Bloomington, the Phosphoria Formation and associated rocks lie in the Paris syncline, which plunges about $15^{\circ} \mathrm{N}$. The western limb of the syncline is overturned; the beds near the trough are nearly vertical, but, high on the limb, they dip as little as $20^{\circ} \mathrm{W}$. The vanadiferous zone is about $35 \mathrm{ft}$ below the top of the Meade Peak Member and about $5 \mathrm{ft}$ below the upper phosphate zone. The zone consists of three beds: a shale, a phosphorite, and a siltstone, in ascending order.
\end{abstract}

Estimates of measured, indicated, and inferred subeconomic resources of vanadium in the Paris-Bloomington area have been prepared for the shale bed, the shale and phosphorite beds combined, and the full thickness of the vanadiferous zone. Measured resources for the full zone are estimated to be 600,000 tons averaging $10.8 \mathrm{ft}$ in thickness and 0.93 percent $\mathrm{V}_{2} \mathrm{O}_{5}$; indicated resources are $4,000,000$ tons averaging $10 \mathrm{ft}$ in thickness and 0.9 percent $\mathrm{V}_{2} \mathrm{O}_{5}$; inferred resources, within the area sampled, are 50 to 75 million tons averaging $10 \mathrm{ft}$ in thickness and 0.6 to 1.0 percent $\mathrm{V}_{2} \mathrm{O}_{5}$.

The vanadiferous zone appears to be the product of primary deposition from upwelling water in a reducing marine environment below wave base in a water depth of $100 \mathrm{~m}$ or so. These deposits formed on the outer continental shelf on the western side of the North American craton at low latitude, where deep, cold, nutrientrich seawater came to the surface as a result of divergent upwelling in a tradewind belt.

The vanadiferous zone in western Wyoming and southeastern Idaho contains about 41 million tons of indicated subeconomic resources averaging about 0.9 percent $\mathrm{V}_{2} \mathrm{O}_{5}$. Inferred resources are many times larger. Eventually, these inferred resources may prove to be an important source of vanadium and several other metals.

\section{INTRODUCTION}

A black shale containing 0.8 to 0.9 percent $\mathrm{V}_{2} \mathrm{O}_{5}$ over a large area was discovered by W.W. Rubey of the U.S. Geological Survey (USGS) in 1938 in the upper part of the Meade Peak Member of the Permian Phosphoria Formation in the Salt River Range of western Wyoming (Rubey, 1943, 1958). This vanadiferous zone, as it came to be called informally, was sampled by the USGS in 1942 at numerous localities in the adjoining region (McKelvey, 1946); it was sampled in more detail in late 1942 and 1943 by the Wyodak Coal and Manufacturing Co., agent for the Metals Reserve Co., in the Paris-Bloomington area of Idaho (McKelvey and Strobell, 1955) and in the Sublette Ridge area of Wyoming. The U.S. Bureau of Mines (USBM) also explored the zone in Sublette Ridge (Allsman and others, 1949a) as well as in the Salt River Range (Allsman and others, 1949b) and investigated means of recovering the vanadium (Ravitz and others, 1947). Information on the geology, composition, and magnitude of the vanadiferous deposits in the Salt River Range was summarized by Love (1961).

These published data are herein supplemented by additional information acquired in the 1942-1943 investigations of the Sublette Ridge and Paris-Bloomington deposits, along with some interpretations of the regional extent, composition, and origin of the zone based in part on subsequent studies (for example, McKelvey and others, 1953, 1959; Gulbrandsen, 1960; Desborough, 1977; E.C.T. Chao, J.A. Minkin, and J.M. Back, written communication, 1986).

\section{REGIONAL EXTENT}

The vanadiferous zone has been found within an area of about $4,500 \mathrm{mi}^{2}$ in western Wyoming, southeastern Idaho, and northeastern Utah (figs. 1, 2). In Wyoming and Utah, the zone is a readily identifiable 


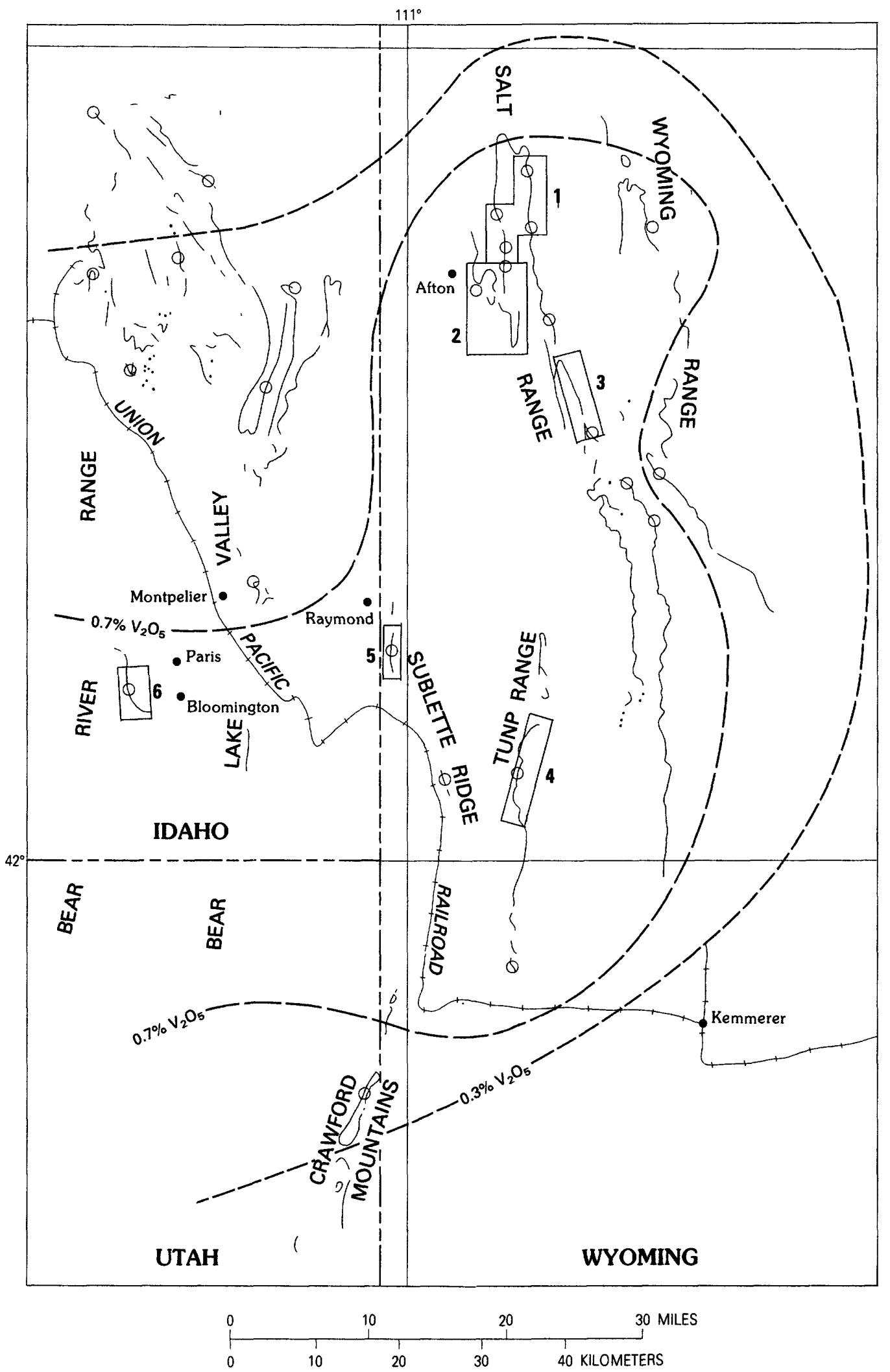

FIGURE 1.-Approximate areal extent of the vanadiferous zone in the upper part of the Meade Peak Member of the Phosphoria Formation, defined on the basis of the area within which a thickness of $3 \mathrm{ft}$ or more contains 0.3 percent $\mathrm{V}_{2} \mathrm{O}_{5}$ or more (shown by short-dash line). Shown also is the area within which one bed or more contains 0.7 percent $\mathrm{V}_{2} \mathrm{O}_{5}$ or more (long-dash line). Outcrops of the Phosphoria Formation are shown by thin lines, and the location of samples for which analyses are shown on figure 2 are marked by open circles. The areas outlined are (1) Swift Creek-McDougal Pass, (2) Afton, (3) Labarge Creek, (4) Tunp Range, (5) Sublette Ridge, and (6) Paris-Bloomington. 


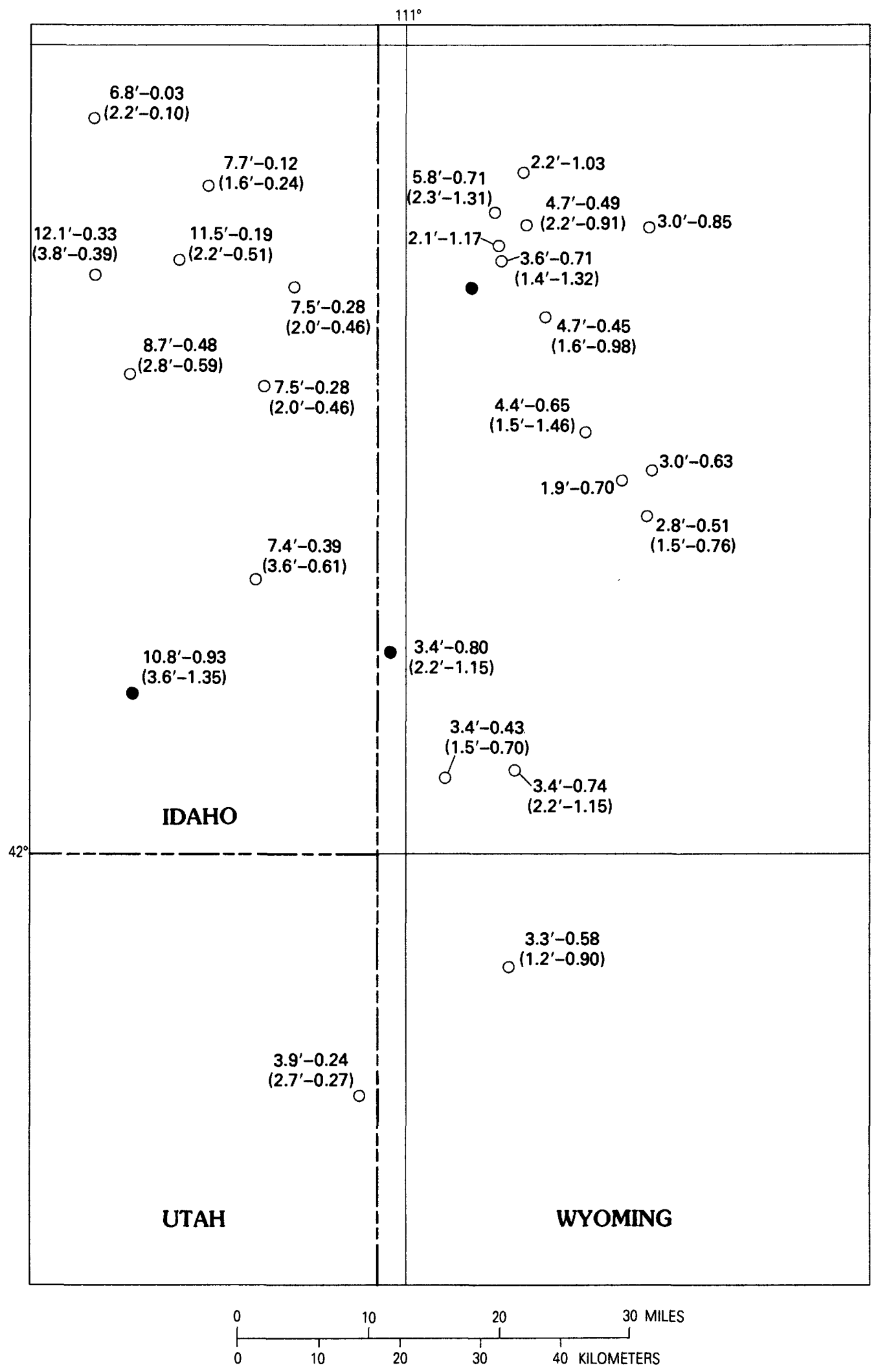

Figure 2.-Selected $\mathrm{V}_{2} \mathrm{O}_{5}$ analyses from the vanadiferous zone (see fig. 1 for position of samples on outcrops of the Phosphoria Formation). Only locations having unfaulted exposures, unaffected by deep weathering, are shown; where available, values of samples taken from the higher grade part of the zone are shown in parentheses. Analyses from locations indicated by solid circles rather than open circles are based on the average of many samples collected by the USBM (Afton area) and the Wyodak Coal and Manufacturing Co. (Sublette Ridge and Paris-Bloomington areas). 
stratigraphic unit 2 to $6 \mathrm{ft}$ thick, consisting of nonphosphatic hard black mudstone that weathers to soft black shale containing conspicuous orange coatings along joint and bedding planes. It is 30 to $100 \mathrm{ft}$ below the base of the Rex Chert Member of the Phosphoria Formation and essentially at the base of the upper phosphate zone of the Meade Peak Member.

In Bear Lake County, Idaho, the zone is 6 to $15 \mathrm{ft}$ thick and also lies at the base of the upper phosphate zone, 25 to $40 \mathrm{ft}$ below the Rex Chert Member. Unlike the zone in Wyoming, it contains a few to several percent $\mathrm{P}_{2} \mathrm{O}_{5}$. The beds are soft and black in weathered exposure, but their phosphate content gives them an appearance different from that of their Wyoming correlatives. Farther north, in Caribou County, the $\mathrm{P}_{2} \mathrm{O}_{5}$ content increases to 20 to 25 percent, and the zone is not distinguishable lithologically from the upper phosphate zone. The presence of the zone is generally indicated by $\mathrm{V}_{2} \mathrm{O}_{5}$ analyses in the range of about 0.35 to 1.0 percent over a thickness of a few feet.

The areal limits of the zone are known only approximately. It is present in the Tunp Range to the east of Sublette Ridge, where it is about $3 \mathrm{ft}$ thick and contains 0.75 to 0.9 percent $\mathrm{V}_{2} \mathrm{O}_{5}$. It is also present in the northern Crawford Mountains of Utah, an occurrence lithologically quite similar to the one farther north but containing much less vanadium. Southward and eastward, the beds of the vanadiferous zone either tongue out or grade into other lithic units; they are not identifiable on the basis of either lithology or vanadium content in the Wasatch or Uinta Mountains. A similar change in facies occurs to the east and north of the Wyoming Range; the zone is not identifiable in the Wind River Mountains, the Gros Ventre Range, or the Snake River Range. The vanadiferous zone may extend westward for some distance, but its vanadium content west of Bear Lake Valley in southeastern Idaho is so low that the zone is not identifiable as such.

A comparison of figures 1 and 3 . shows that the vanadiferous zone extends over that part of the Meade Peak Member richest in organic C, P, V, and Ag. However, the zones highest in vanadium lie to the east and south of the carbon-, phosphorous-, and silver-rich zones.

The Salt River Range near Afton, Wyo. Sublette Ridge, and the Paris-Bloomington area were selected for further exploration within the area underlain by the vanadiferous zone because of their potential minability, judged on the basis of the vanadium content of the zone and the relatively uncomplicated structural settings. Should exploitation of the vanadiferous zone become economic, however, they would not be the only possibly minable areas.

\section{SUBLETTE RIDGE DEPOSITS}

Sublette Ridge lies in the western part of Lincoln County, Wyoming, about $1 \mathrm{mi}$ east of the Idaho State line. It is a northward-trending ridge of mountainous relief on the eastern side of Thomas Fork Valley. Raymond Canyon, the main point of entry to the deposit, is about $2 \mathrm{mi}$ east of Raymond, Idaho. The Union Pacific Railroad at Border, Wyo., is about $7 \mathrm{mi}$ by road from Raymond Canyon.

During the winter of 1942-1943, the Wyodak Coal and Manufacturing Co. and the USBM undertook exploration programs. Fifty-four trenches spaced 200 to $1,000 \mathrm{ft}$ apart were dug, and 13 tunnels and a shaft were driven.

\section{GEOLOGY}

Vanadium is present in small amounts in many of the beds of the Meade Peak Member of the Phosphoria Formation, but only the vanadiferous zone, lying about $50 \mathrm{ft}$ below the top of the member, contains amounts of possible economic interest. The Meade Peak Member is underlain by the Grandeur Member of the Park City Formation and overlain by the Rex Chert Member of the Phosphoria Formation.

These formations occur on the eastern limb of the Sublette anticline, the axis of which strikes north along the western front of Sublette Ridge. The western limb of the anticline has been downthrown by normal faulting, and most of it is buried beneath Holocene and Tertiary(?) alluvium in Thomas Fork Valley. A part of the western limb is exposed in the northern part of the area east of the fault for a short distance. The Phosphoria Formation extends over a strike length of 6.5 $\mathrm{mi}$ in Sublette Ridge but is concealed by younger rocks for a distance of $1.5 \mathrm{mi}$ north of Petereit Gulch. The beds are nearly vertical along the flank of the anticline but dip as low as $45^{\circ}$ in places near the crest. Numerous faults marked by small displacements cut the vanadiferous zone.

\section{VANADIFEROUS ZONE}

The vanadiferous zone in the Sublette Ridge area consists of seven layers of black mudstone overlain by a hard, massive, fossiliferous limestone about $2 \mathrm{ft}$ thick and underlain by an equally hard and massive but locally lenticular limestone. The beds are soft and fissile near the surface, but, about $40 \mathrm{ft}$ beneath the surface, they abruptly become hard and massive; the layers there are separated from one another by barely discernible cracks. Orange coatings, probably the 
SUBLETTE RIDGE DEPOSITS
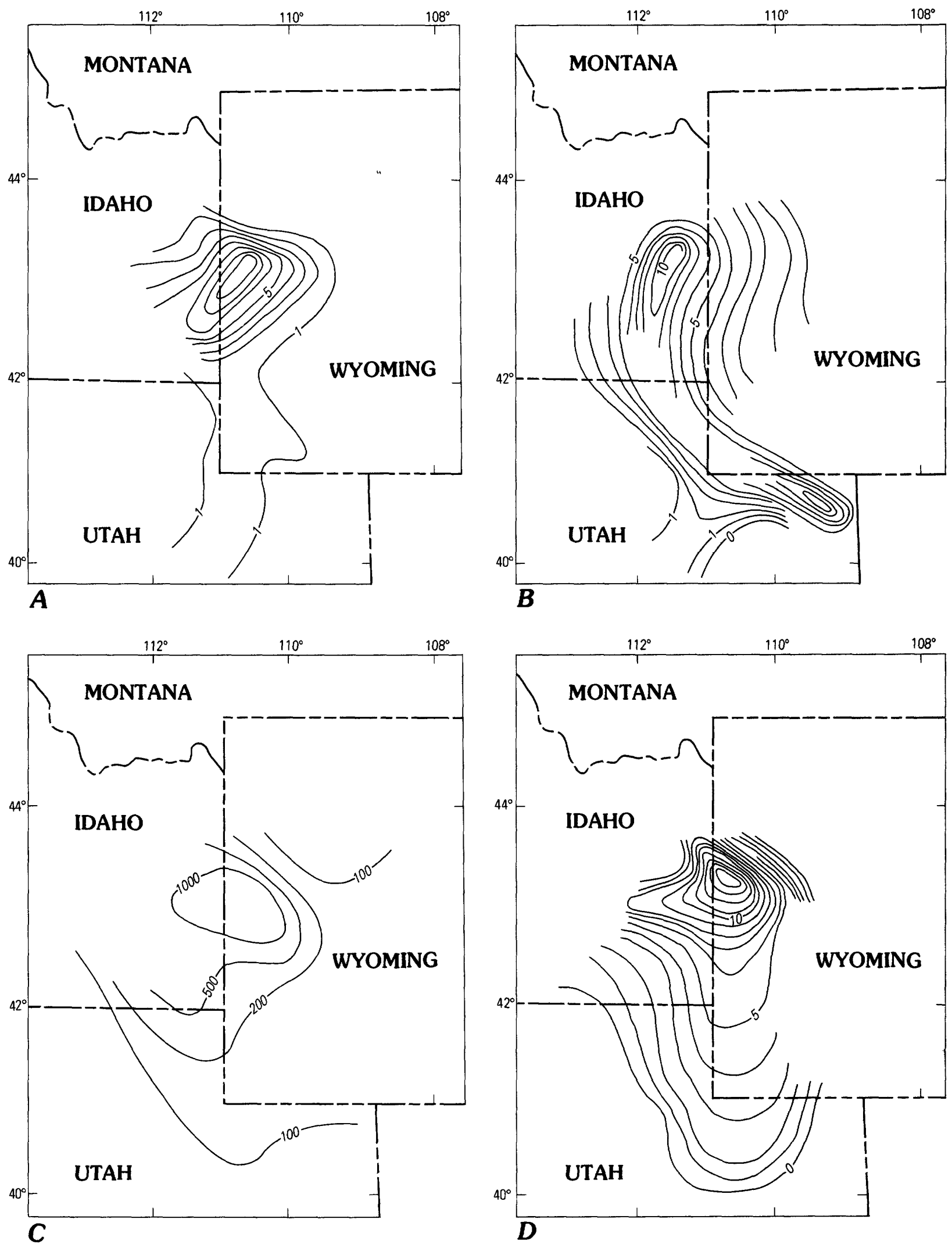

FiguRE 3.-A verage concentrations of $(A)$ organic C (in percent), $(B) \mathrm{P}$ (in percent), $(C) \mathrm{V}$ (in parts per million), and $(D) \mathrm{Ag}$ (in parts per million) in the Meade Peake Member of the Phosphoria Formation (after Maughan, 1976, 1980). 
result of pyrite oxidation, are prominent on bedding and joint surfaces of the weathered rocks. Although weathering produced the effects just described, it did not mobilize the vanadium in this area, for the vanadium content is essentially the same in both fresh and weathered parts of the zone.

The full vanadiferous zone is 2.5 to $4.3 \mathrm{ft}$ thick and averages about $3.4 \mathrm{ft}$. Most of the vanadium is concentrated in the upper 1.5 to $2.5 \mathrm{ft}$ of the zone. The $\mathrm{V}_{2} \mathrm{O}_{5}$ content of the whole zone ranges from 0.45 to 1.05 percent and averages about 0.8 percent. During the early stages of the work, it was assumed that the shaly nature of the rocks would require mining the full width of the zone between the hanging-wall and the footwall limestone beds; consequently, the zone was sampled as a unit in most of the trenches (pl. 1). After hard, unweathered rock was encountered in underground workings, attention was given to mining only the upper, more vanadiferous part of the zone, which avernges about 1.05 percent $\mathrm{V}_{2} \mathrm{O}_{5}$ over a width of $2.25 \mathrm{ft}$.

The individual layers of the zone are remarkably continuous stratigraphically, and their vanadium contents are similar throughout the area (pl. 2). In fact, essentially the same sequence is found some $40 \mathrm{mi}$ to the north in the Afton area, where the same rich central part of the zone (pl. 1) is 0.5 to $1.0 \mathrm{ft}$ thick and averages 1.6 percent $\mathrm{V}_{2} \mathrm{O}_{5}$ (maximum 2.5 percent) (Love, 1961), about the same as the values found in Sublette Ridge. Although these layers are recognizable in the field on the basis of physical properties, the distinctions between them are slight, and they were not recognized during the 1942 reconnaisance sampling when the zone was generally sampled as a unit. It seems likely that these same layers are also present at other localities in western Wyoming where the zone has been found.

The USBM reported partial analyses of several samples, as table 1 shows (Ravitz and others, 1947). The locations and thicknesses represented by these samples were not reported, but, because the $\mathrm{V}_{2} \mathrm{O}_{5}$ content is in the range of 0.52 to 0.92 percent, it is assumed that they represent the full thickness of the zone. The analyses suggest that the main constituents of the rocks are quartz-silicate minerals, organic matter, carbonate minerals, and pyrite.

Relatively complete chemical analyses were made by the Tennessee Valley Authority on all of the beds of the Meade Peak Member sampled in 1947 by a USGS field party in Coal Canyon, ${ }^{1}$ about $1 \mathrm{mi}$ south of Raymond Canyon (McKelvey and others, 1953). Analyses for the beds of the vanadiferous zone and the hanging-wall and footwall limestones are shown in table 2. Gulbrandsen (1960) determined the vanadiferous beds to be quartz-silicate rocks containing grains of quartz, feldspar, and mica in a matrix of illite, organic matter, pyrite, and dolomite. Because of its odor, he believed part of the organic matter to be bituminous. Spectrographic analyses of minor elements in two of the beds of the zone are listed in table 3.

Desborough (1977) later collected samples from the vanadiferous zone in Coal Canyon intended to correspond to the same beds sampled in 1947 and had them analyzed for the constituents shown in table 4 . On the basis of electron microprobe, optical, and chemical studies, he concluded (Desborough, 1977, p.

\footnotetext{
${ }^{1}$ Now shown as Rose Canyon on the USGS topographic map of the Geneva $7^{2}-$-min quadrangle
}

TABLE 1.-Partial chemical analyses (in ut perent) of the ranadiferous zone at Sublette Ridge. Wyo. (from Raritzand others. 194i)

[LOI, loss on ignition: n.d., not determined]

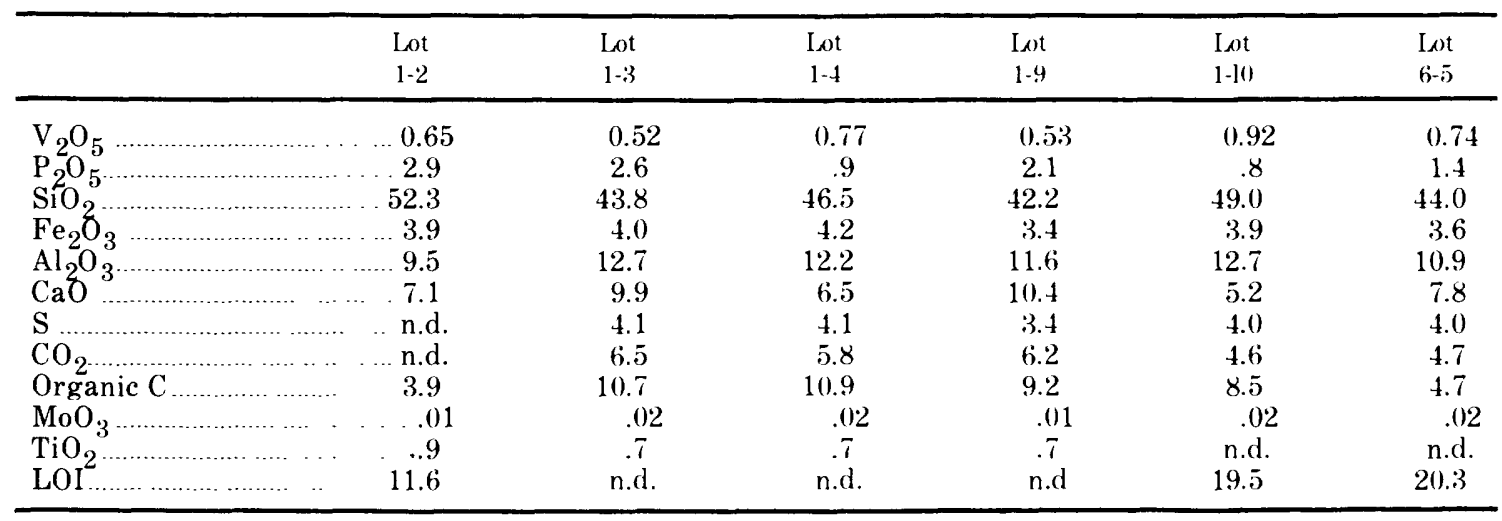


TABLE 2.-Chemical analyses of the nanadiferous zone and adjacent limestones (in wit percent) at Coal Canyon, Wyo. [U and Se determinations by the U.S. Geological Survey; all others by the Tennessee Valley Authority under the direction of J.H. Walthall (McKelvey and others, 1953; Gulbrandsen, 1960). AI, acid insoluble; LOI, loss on ignition; n.d., not determined; no entry, not analyzed]

\begin{tabular}{|c|c|c|c|c|c|c|}
\hline \multirow[b]{2}{*}{$\begin{array}{l}\text { Bed } \\
70^{2} \\
\end{array}$} & \multicolumn{5}{|c|}{ Vanadiferous zone $\mathrm{e}^{1}$} & \multirow[b]{2}{*}{$\begin{array}{l}\text { Bed } \\
76^{3} \\
\end{array}$} \\
\hline & $\begin{array}{l}\text { Bed } \\
71\end{array}$ & $\begin{array}{l}\text { Bed } \\
72\end{array}$ & $\begin{array}{c}\text { Bed } \\
7: 3\end{array}$ & $\begin{array}{l}\text { Bed } \\
74\end{array}$ & $\begin{array}{c}\text { Bed } \\
7.5\end{array}$ & \\
\hline$\ldots \ldots \ldots$ & 15.60 & 4.20 & 4.20 & 6.05 & 8.40 & 50.22 \\
\hline 1.8 & 1.4 & 2.9 & 2.7 & 2.3 & 1.9 & 1.8 \\
\hline $\mathrm{CO}_{2} \ldots 29.3$ & 6.4 & 5.6 & 5.1 & 5.9 & 5.0 & 40.2 \\
\hline $\mathrm{P}_{2} \mathrm{O}_{5} \ldots \ldots \ldots \ldots \ldots$ & 6.30 & .5 & .20 & .34 & 2.73 & .36 \\
\hline $\mathrm{SiO}_{2}$ & 37.36 & 52.58 & 45.64 & 41.64 & 47.18 & 4.82 \\
\hline $\mathrm{Al}_{2} \mathrm{O}_{3} \ldots$ & 7.1 & 9.7 & 9.6 & 9.8 & 8.6 & 1.1 \\
\hline $\mathrm{Fe}_{2} \mathrm{O}_{3}$ & 3.3 & 4.4 & 4.0 & 3.9 & 3.4 & .5 \\
\hline $\mathrm{Na}_{2} \mathrm{O} \ldots$ & 1.27 & 1.30 & .99 & .78 & 1.25 & .60 \\
\hline 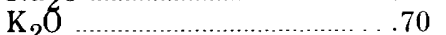 & 2.11 & 2.85 & 2.78 & 2.55 & 2.12 & .72 \\
\hline $\mathrm{TiO}_{2} \ldots \ldots \ldots \ldots \ldots \ldots$ & .28 & .36 & .23 & .18 & .52 & .03 \\
\hline $\mathrm{V}_{2} \mathrm{O}_{5}$ & .14 & .37 & 1.45 & 1.75 & .52 & .06 \\
\hline $\mathrm{S}$ as $\mathrm{SO}_{3}$ & 9.4 & 8.4 & 10.6 & 12.5 & 8.6 & .44 \\
\hline $\mathrm{H}_{2} \mathrm{O}$ & .37 & .32 & .52 & $.8: 3$ & .51 & .13 \\
\hline - & 46.66 & 65.75 & 56.38 & 51.2 & 59.30 & 5.90 \\
\hline$\ldots \ldots \ldots \ldots \ldots \ldots \ldots$ & 17.4 & 16.6 & 22.6 & 24.9 & 16.7 & 41.1 \\
\hline 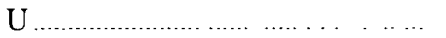 & & $.0005-.004$ & & & & \\
\hline n.d. & .009 & .010 & .015 & .015 & .015 & n.d. \\
\hline
\end{tabular}

\footnotetext{
${ }_{2}^{1}$ Beds 71 through 75 are from base to top of vanadiferous zone.

${ }_{3}^{2}$ Footwall limestone.

${ }^{3}$ Hanging-wall limestone.
}

1) that "V is in, or associated with, organic material and minor amounts of $\mathrm{V}$ are in $\mathrm{Ti}-\mathrm{Fe}$ oxysulfide and an unidentified $\mathrm{Fe}$ sulfide; $\mathrm{Cr}$ is in a $10 \mathrm{~A}$ mica. $\mathrm{Zn}$ and $\mathrm{Cd}$ are in sphalerite; $S$ e is in pyrite; $S$ is in pyrite,

TABLE 3.-Minor elements (in ppm) in two beds of the nanadiferous zone at Coal Canyon, Wyo.

[Semiquantitative spectrographic analyses by Harry Bastron. cited by Gulbrandsen (1977). n.d., not detected]

\begin{tabular}{|c|c|c|}
\hline Element & $\begin{array}{l}\text { Bed } \\
\text { P-72 }\end{array}$ & $\begin{array}{l}\text { Bed } \\
\text { P-73 }\end{array}$ \\
\hline $\mathrm{Ag}$. & 7 & 10 \\
\hline $\mathrm{B}$ & 70 & 100 \\
\hline $\mathrm{Ba}$ & 300 & 300 \\
\hline $\mathrm{Be} \ldots \ldots \ldots$ & n.d. & 1 \\
\hline $\mathrm{Co}$ & 7 & 7 \\
\hline $\mathrm{Cr}$ &. .500 & 1,000 \\
\hline $\mathrm{Cu}$ & $\ldots 70$ & 100 \\
\hline $\mathrm{Ga}$ & $\ldots 10$ & 15 \\
\hline $\mathrm{Mn}$ & 200 & 150 \\
\hline Mo & 150 & 300 \\
\hline $\mathrm{Ni}$ & 200 & 700 \\
\hline $\mathrm{Pb}$ & $\ldots 20$ & 20 \\
\hline $\mathrm{Sc}$ & 15 & 15 \\
\hline $\mathrm{Sr}$ & .150 & 150 \\
\hline $\mathrm{V}$ & 5,000 & 7,000 \\
\hline Y & $\ldots .50$ & 30 \\
\hline $\mathrm{Yb}$ & 7 & 20 \\
\hline $\mathrm{Zn}$ & 700 & 15,000 \\
\hline $\mathrm{Zr}$. & 300 & 300 \\
\hline
\end{tabular}

sphalerite, and organic material; $\mathrm{Ti}$ is in $\mathrm{TiO}_{2}$ and $\mathrm{Ti}_{2} \mathrm{Fe}\left(\mathrm{SO}_{3} \mathrm{O}_{2}\right.$; and Mo is in powellite."

Agreement among these analyses for minor elements, made by different methods on different samples, leaves much to be desired, but they nevertheless support an interesting observation: a sizable group of elements-Ag, $\mathrm{Cd}, \mathrm{Cr}, \mathrm{Cu}, \mathrm{Ga}, \mathrm{Mo}, \mathrm{Ni}$, and $\mathrm{Zn}-$ roughly follow $\mathrm{V}$ in their concentrations. As table 3 shows, for example, an increase in $\mathrm{V}$ by a factor of 1.4 from bed P-72 to P-73 is paralleled by a 1.43 increase for $\mathrm{Ag}$ and $\mathrm{Cu}$, a 1.5 increase for $\mathrm{Ga}$, a 2.0 increase for $\mathrm{Cr}$ and $\mathrm{Mo}$, and a 3.5 increase for $\mathrm{Ni}$. (The 21.4 factor of increase shown for zinc may be a gross error; the value of $700 \mathrm{ppm}$ shown for bed P-72 probably should be 7,000 ppm.)

In a further attempt to define the site of the vanadium, E.C.T. Chao (written communication, 1985) undertook a study of a doubly polished thin section prepared by Cheryl Edwards from a chip of sample VEM 42-47 from the zone in Coal Canyon. He reported that:

The pyritiferous, carbonaceous black shale, VEM $42-47$, is a very fine-grained shale with most grains less than $\mathbf{5 0}$ micrometers in size. It contains several larger (up to a few tenths of $\mathrm{mm}$ ) fossil fragments. The dominant minerals are as follows: Quartz (many with less than 10 micrometer size pyrite inclusions), detrital calcite (both single crystal fragments and aggregates), illite (platy micaceous clay), 
TABLE 4.-Analyses of selected constituents of the vanadiferous zone at Coal Canyon, Wyo. (from Desborough, 1977)

[n.d., not determined]

\begin{tabular}{|c|c|c|c|c|}
\hline & $\begin{array}{c}\text { Bed } \\
72-\mathrm{CC}\end{array}$ & $\begin{array}{c}\text { Bed } \\
73-\mathrm{CC}\end{array}$ & $\begin{array}{c}\text { Bed } \\
74-\mathrm{CC}\end{array}$ & $\begin{array}{c}\text { Bed } \\
75-\mathrm{CC}\end{array}$ \\
\hline Total $C{ }^{1}$ in percent. & .9 .24 & 8.13 & 8.16 & 14.08 \\
\hline Carbonate $\mathrm{C}, 2$ in percent. & 1.34 & 1.63 & 1.16 & 1.28 \\
\hline Organic C 3 in percent & 7.9 & 6.5 & 7.0 & 12.8 \\
\hline Total $\mathrm{S},{ }^{4}$ in percent & 3.38 & 3.03 & 3.38 & 4.34 \\
\hline $\mathrm{V} 5$ in percent & .00 & .14 & .19 & .95 \\
\hline $\mathrm{Zn}, 6$ in percent & $\ldots .05$ & .09 & .09 & .69 \\
\hline $\mathrm{Cd},{ }^{6}$ in percent & n.d. & .007 & .01 & .07 \\
\hline $\mathrm{Ag}_{2}{ }^{6}$ in $\mathrm{ppm}$ & 6. & 5. & 6. & 10. \\
\hline $\mathrm{Ti},{ }^{\text {in }} \mathrm{ppm} . . . . . .$. & 00. & 2,000 & 2,000 & 2,000 \\
\hline Mo, ${ }^{7}$ in ppm & 50. & 100. & 70. & 300. \\
\hline
\end{tabular}

${ }_{2}^{1}$ Combustion, gasometric $\mathrm{CO}_{2}$

${ }^{2} \mathrm{H}_{3} \mathrm{PO}_{4}$ digestion.

3 Difference between 1 and 2 .

${ }_{5}^{4}$ Combustion.

5 Colorimetric.

${ }_{7}^{6}$ Atomic absorption.

7 Semiquantitative six-step spectrographic.

8 X-ray fluorescence.

sphalerite (both single crystal fragments and in finegrained aggregates), and abundant pyrite both granular and framboidal.

In addition, this black shale contains very fine grained $(10 \mu \mathrm{m})$ or less in grain size) lithic fragments of clay lenses consisting of quartz and illite in a brownish dark matrix. The black shale also contains fairly abundant thin lenses and fragments of semifusinite (tentatively identified by its optical characteristics), a maceral of the inertinite group of coal. It also contains several opaque minerals, unidentified minerals such as a K-Al-silicate of low birefringence, rutile, zircons, plagioclase feldspar, and other accessory minerals. Authigenic secondary overgrow ths on quartz have been observed but they are extremely rare. Based on two qualitative analyses, the $\mathrm{V}$ is contained in fragments of semifusinite, One grain without sphalerite, the other with inclusions of sphalerite. This suggests that semifusinite (an aromatic hydrocarbon of terrestrial plant origin) is the host of $\mathrm{V}$ in this rock. This would support George Desborough's earlier finding... Phosphorus is present in the fossil fragments.... This black shale contains an unusual amount of sphalerite with traces of cadmium. in isolated grains and in fine aggregates, apparently of sedimentary origin. The presence of framboidal pyrite, detrital calcite, phosphatic fossil fragments, and coaly fragments (and its $V$ content) provide clues to the depositional enviroment...(anaerobic enviroment with dominant marine influence).

On the basis of its nonfluorescence in ultraviolet illumination, most of the organic matter is judged to be semifusinite. Because of its fine-grained mineral impurities, however, it is not uniform in composition. The electron microprobe analyses shown in table 5 were made by J.A. Minkin and J.M. Back (written communication, 1986) and selected from 25 such analyses of randomly selected semifusinite areas in the doubly polished thin section of VEM 42-47. The electron beam focuses on an area a few micrometers in width, so that the analysis reflects the composition of any impurities present. Because the electron microprobe does not detect light elements, such as carbon and hydrogen, the difference between the total shown and 100 percent can be assumed to be largely organic matter. Chao grouped these analyses on the basis of their composition, as table 5 shows. For example, analyses having a low total of inorganic constituents are assumed to be nearly pure semifusinite; potassium is assigned to illite; iron is assigned to pyrite, and excess sulfur is assumed to be organic; phosphorus is assumed to be in apatite.

These analyses show that the vanadium in the semifusinite is likely to be in more than one form. Some of it clearly is in organic matter, since the nearly pure semifusinite contains appreciable amounts of vanadium. Because the highest amounts - up to 4.2 percent $\mathrm{V}_{2} \mathrm{O}_{3}\left(5.1\right.$ percent $\left.\mathrm{V}_{2} \mathrm{O}_{5}\right)$-are in the areas composed mainly of illite, however, some vanadium may be attached to that mineral. Some may also be in apatite, although the areas containing apatite also contain the lowest amounts of vanadium. The presence of appreciable amounts of vanadium in association with the unidentified minerals of groups 6 and 7 in table 5 suggest that it may be in or attached to one or more other minerals also. 
TABLE 5.-Selected electron microprobe analyses (in percent) of sem ifusinite areas in sample VEM 42-47 from the vanadiferous zone of the Meade Peak Member of the Phosphoria Formation at Coal Canyon, Wyo.

[J.A. Minkin and J.M. Back, analysts; characterization of groups by E.C.T. Chao (written communication, 1986). n.d., no data; --, not present]

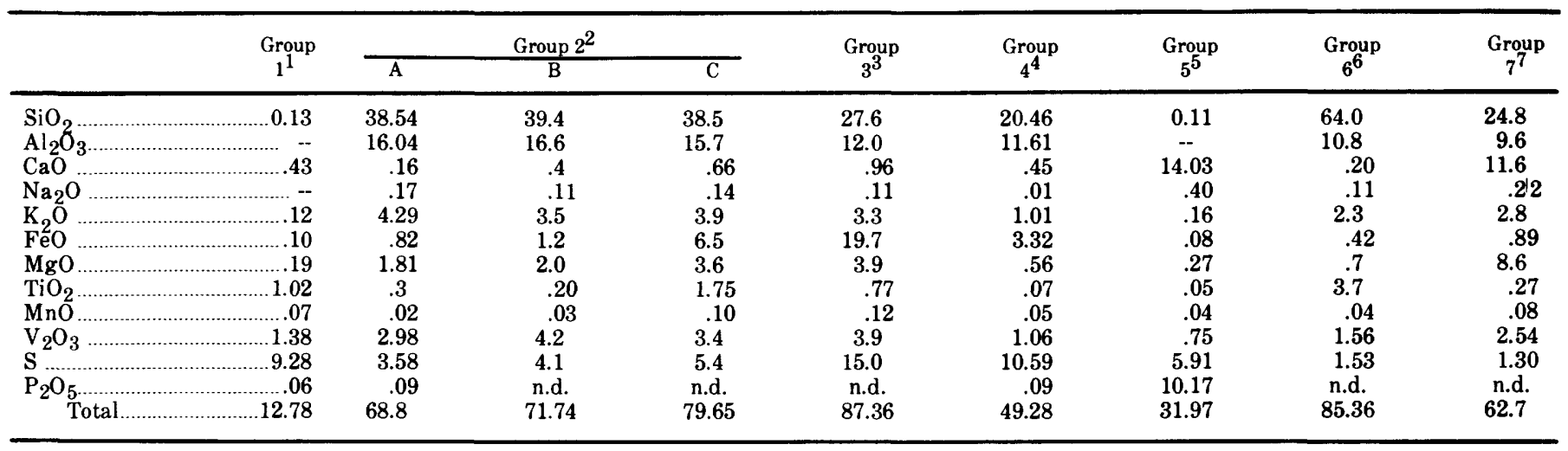

${ }_{2}^{1}$ Nearly pure semifusinite. Six samples in group show $\mathrm{V}_{2} \mathrm{O}_{3}$ range of 1.23 to 2.22 percent.

${ }^{2}$ Semifusinite having appreciable illitic clay, quartz, and low to moderate pyrite content. Four samples in group show $\mathrm{V}_{2} \mathrm{O}_{3}$ range of 1.6 to 4.2 percent.

${ }^{3}$ Semifusinite having moderate illitic clay and high pyrite content. Three samples in group show $\mathrm{V}_{2} \mathrm{O}_{3}$ range of 1.96 to 3.9 percent.

${ }_{5}^{4}$ Semifusinite having high organic sulfur, moderate ash, and moderate pyrite. Four samples in group show $\mathrm{V}_{2} \mathrm{O}_{3}$ range of 1.46 to 2.51 percent.

${ }^{5}$ Semifusinite containing apatite. Four samples in group show $\mathrm{V}_{2} \mathrm{O}_{3}$ range of 0.65 to 1.08 percent.

${ }_{7}^{6} \mathrm{As}$ yet unidentified mineral containing $\mathrm{Si}, \mathrm{Al}, \mathrm{Ti}, \mathrm{K}$, and $\mathrm{Mg}$. One sample.

${ }^{7}$ As yet unidentified mineral(s) characterized by moderately high $\mathrm{Si}$, high Ca and $\mathrm{Mg}$, and moderate $\mathrm{Al}$. Two samples show $\mathrm{V}_{2} \mathrm{O}_{3}$ range of 1.05 to 2.54 percent.

\section{RESOURCES}

The Wyodak Coal and Manufacturing Co. estimated that the vanadiferous zone in the explored part of Sublette Ridge contains about 1.9 million tons above drainage level averaging about 0.8 percent $\mathrm{V}_{2} \mathrm{O}_{5}$. Experimental stoping indicated that the upper $2.25 \mathrm{ft}$ of the zone, averaging 1.06 percent $\mathrm{V}_{2} \mathrm{O}_{5}$, could be mined separately by the shrinkage method of mining. This uppermost part of the zone contains about 1.35 million tons.

The feasibility of mining these rocks commercially has not been demonstrated. Hence, these quantities can be classed as indicated subeconomic resources.

\section{PARIS-BLOOMINGTON DEPOSITS}

The Paris-Bloomington area of Idaho is in Bear Lake County, in the eastern foothills of the Bear River Range. It is about $1 \mathrm{mi}$ west of the towns of Paris and Bloomington and $10 \mathrm{mi}$ southwest of the Union Pacific Railroad at Montpelier. The hills are low and rounded, local relief being about $500 \mathrm{ft}$. They are cut by four eastward-flowing streams-from north to south, Hammond Creek, Sleight Creek, Paris Creek, and Bloomington Creek - that head in the mountains to the west.

From March to December 1943, the Wyodak Coal and Manufacturing Co., agent for the Metals Reserve Co., sampled the Paris-Bloomington deposits in nearly $2,500 \mathrm{ft}$ of underground workings and in six trenches and short adits. For its part in this project, the USGS prepared a geologic strip map of the area adjacent to the trace of the vanadiferous zone and a geologic map of the area underlain by the zone, both later published at scales of 1:4800 and 1:12,000, respectively (McKelvey and Strobell, 1955). The average thicknesses and vanadium contents of the beds of the zone in surface and underground workings are shown on these maps, as are the locations of geologic and geographic features mentioned in this report.

\section{GEOLOGY}

Rocks exposed in the area include the Phosphoria Formation (Permian), the overlying Dinwoody, Woodside, and Thaynes Formations (Triassic), and the underlying Grandeur Tongue of the Park City Formation (Permian) and the Wells Formation (Pennsylvanian and Permian). Brigham Quartzite and Ute(?) Limestone (Cambrian) are in fault contact with these rocks along the Paris overthrust (Armstrong and Cressman, 1963). Tertiary conglomerate, sandstone, and gravel overlie and conceal these Mesozoic and Paleozoic rocks, especially in the southern part of the area. Alluvium, slope wash, and talus of Quaternary age mantle much of the area.

The Phosphoria Formation is divided into the Meade Peak Member, about $200 \mathrm{ft}$ thick, and the overlying Rex Chert Member and cherty shale members, about $250 \mathrm{ft}$ in combined thickness. The top of the vanadiferous zone is about $35 \mathrm{ft}$ below the Rex Chert 
Member and about $5 \mathrm{ft}$ below the upper phosphate zone of the Meade Peak.

The Phosphoria Formation and associated formations lie in the asymmetrical Paris syncline, whose axial plane dips about $35^{\circ} \mathrm{W}$.; the axis plunges about $15^{\circ} \mathrm{N}$. south of Paris Canyon but flattens northward to about $5^{\circ}$ or less. The western limb of the syncline is overturned; its beds are nearly vertical near the trough of the syncline, but, high on the limb, they dip as little as $20^{\circ} \mathrm{W}$. The beds on the eastern normal limb $\operatorname{dip} 10^{\circ}$ to $35^{\circ}$ N.-NNW.

The beds on the western limb are tightly squeezed and decrease in thickness with increasing distance above the trough. At vertical distances of 1,000 to $2,500 \mathrm{ft}$ above the trough, large parts of the incompetent formations are cut out by reverse faults, which are nearly parallel to the bedding. Because of the northward plunge of the syncline, these bedding faults increase in abundance at the surface and progressively appear in stratigraphically higher beds. Thus, a bedding fault cuts out most of the Meade Peak Member at the surface north of Paris Canyon, but no such faults of any size are known in the member south of it.

Four major transverse faults displace the Meade Peak Member as much as 1,000 $\mathrm{ft}$. Minor transverse faults, many of less than $5 \mathrm{ft}$ displacement, and drag folds that cause local thickening or thinning of the beds are abundant on the overturned limb of the syncline. The beds on the normal limb are little disturbed but in places are warped or broken by faults of a few feet displacement.

The Paris thrust plate once overlay the entire area but has been eroded back to the west. South of Sleight Canyon, its margin now lies 500 to $2,000 \mathrm{ft}$ west of the Meade Peak Member on the overturned limb. North of Sleight Canyon, however, the Paris thrust plate overlies the entire Phosphoria Formation as well as the Dinwoody and Woodside Formations. The Paris fault plane dips westward $45^{\circ}$ in Bloomington Canyon and decreases northward to $5^{\circ}$ at Hammond Creek.

\section{VANADIFEROUS ZONE}

The vanadiferous zone is composed of three beds: in ascending order, a shale, a phosphorite, and a siltstone (table 6). These beds are stratigraphically continuous throughout the area. Small amounts of vanadium are found in other beds of the Meade Peak Member, mainly in and near the lower and upper phosphate beds and in the beds adjacent to the vanadiferous zone. Although these adjacent beds are locally enriched as a result of weathering, other beds in the Meade Peak Member for the most part contain less than 0.2 percent $\mathrm{V}_{2} \mathrm{O}_{5}$.
TABLE 6.-Average thicknesses and $V_{2} O_{5}$ contents of the beds of the vanadiferous zone, based on all available samples

[All vanadium analyses for the Paris-Bloomington deposits made by W.E. Ryan of the Wyodak Coal and Manufacturing Co.]

\begin{tabular}{lcc}
\hline Bed & $\begin{array}{c}\text { Average thickness, } \\
\text { in } \mathrm{ft}\end{array}$ & $\begin{array}{c}\text { Average } \mathrm{V}_{2} \mathrm{O}_{5} \text { content, } \\
\text { in percent }\end{array}$ \\
\hline Siltstone & 4.30 & 0.87 \\
Phosphorite & .5 .20 & .54 \\
Shale &. .3 .4 & 1.38 \\
Total &. .97 \\
\hline
\end{tabular}

The shale bed (the lower part of the zone) is black, medium hard, and fissile. The upper $1 \mathrm{ft}$ contains some thin oolitic phosphorite layers, and the lower 6 to 8 in are in places more coarsely bedded and blocky. In the lower part of a winze in Paris Canyon, about $200 \mathrm{ft}$ below adit level, the whole bed is calcareous, hard, and less fissile. Where the rock is moderately weathered, it is soft and clayey, bedding is indistinct, and its color is dark brown to tan. Lenses of black massive siltstone are found locally in the shale bed, particularly in the upper part. They range from 0.3 to $3 \mathrm{ft}$ thick and from 1 to $25 \mathrm{ft}$ long. Most of these lenses are soft and earthy, but, in places, some are hard and calcareous, and the change from hard to soft may be abrupt. The shale bed in the Paris-Bloomington workings, including the lenses, averages $3.4 \mathrm{ft}$ in thickness and 1.38 percent $\mathrm{V}_{2} \mathrm{O}_{5}$. It also contains about 12 percent $\mathrm{P}_{2} \mathrm{O}_{5}$. Most of the lenses contain less than 0.2 percent $\mathrm{V}_{2} \mathrm{O}_{5}$.

The phosphorite bed is black, massive, hard, and coarsely oolitic and has some shaly siltstone interbedded in the upper half. Where the bed is weathered, it is soft and dark brown to tan, crumbly in the lower part and clayey in the upper part. A few oolite lenses occur between the massive and shaly parts of the bed; they range from 0.5 to $1 \mathrm{ft}$ thick and are generally less than $10 \mathrm{ft}$ long. The average thickness of the phosphorite is $2.20 \mathrm{ft}$, and its average $\mathrm{V}_{2} \mathrm{O}_{5}$ content is 0.54 percent; the $\mathrm{P}_{2} \mathrm{O}_{5}$ content is about 23 percent.

Lenses of siltstone 0.5 to $3.0 \mathrm{ft}$ thick and as much as $80 \mathrm{ft}$ long locally occur at the contact of the phosphorite and the siltstone beds. The $\mathrm{V}_{2} \mathrm{O}_{5}$ content is generally low but may be high locally as the result of secondary enrichment.

The siltstone bed is black, medium hard, blocky, and well bedded. Individual layers are 2 to 8 in thick. A soft, shaly layer as much as $1 \mathrm{ft}$ thick is locally developed at the top of the bed. In the lower part of the Paris Canyon winze, the bed is massive, hard, and somewhat calcareous. Where it is weathered, it is soft, clayey, and dark to light brown. Its average thickness is $4.3 \mathrm{ft}$, and its average $\mathrm{V}_{2} \mathrm{O}_{5}$ content is 0.87 percent; it contains about 3 percent $\mathrm{P}_{2} \mathrm{O}_{5}$. 
The beds adjacent to the vanadiferous zone are mainly siltstone. Unweathered beds stratigraphically below the zone are hard and calcareous and form a good hanging wall for mining where the zone is on the overturned limb of the syncline. Where these beds are weathered, however, they are soft and require much timbering to hold as a hanging wall. The siltstone stratigraphically above the zone is hard, massive, oolitic, and yellowish brown and contains about 16 percent $\mathrm{P}_{2} \mathrm{O}_{5}$. On the normal limb of the syncline, this bed forms the hanging wall and, in most of the workings, will hold for only a day or two without support.

Several partial chemical analyses of the vanadiferous beds are shown in tables 7 through 10 . The major constituents of the zone are, in order of abundance, silica, organic matter, calcium, phosphate, and alumina. Quartz-silicate minerals and organic matter are the dominant components of the shale and siltstone beds, although carbonate minerals make up 15 to nearly 30 percent of the shale bed in the lower part of the Paris Canyon winze. Organic matter seems to make up about a quarter of the rock, but little is known as to its nature. Some of the rock has an odor of petroleum, and part of the organic matter may be hydrocarbon. Whatever its form, it is readily combustible; the stockpiles at the 14 South incline caught fire spontaneously in January 1944 and burned vigorously.

Most of the phosphorite bed is composed of carbonate fluorapatite, approximately $\mathrm{Ca}_{9.7} \mathrm{Mg}_{.1} \mathrm{Na}_{.2}\left(\mathrm{PO}_{4}\right)_{5.6}$ $\left(\mathrm{Co}_{3}\right)_{1}\left(\mathrm{CO}_{3} \mathrm{~F}\right)_{3 .} \mathrm{F}_{2}$, according to Gulbrandsen (Manheim and Gulbrandsen, 1979). This mineral is probably also the site of the lesser amounts of phosphate in the shale and siltstone beds.

Minor constituents of the zone include Fe, S, K, F, $\mathrm{Na}, \mathrm{Ti}$, and $\mathrm{Mg}$, in approximate order of abundance. Much of the iron is in hydrous oxides in the weathered rocks and in sulfides in the fresh rocks. Some of the sulfur may be in organic matter. Potassium and sodium, as well as some of the iron and magnesium, are probably present in silicate minerals. Most of the magnesium is probably combined with calcium in dolomite. The fluorine is in the carbonate fluorapatite.

Beds P-142 and P-143 (table 10) are from the upper part of the shale beds, and P-148 is from the phosphorite; the other samples are from the siltstone in the upper part of the vanadiferous zone. Several things in these analyses are worth noting. One is the large amount of organic matter in all the beds. Another is that 49 elements (counting organic matter as carbon) have been detected in the zone. Many of the elements are present in relatively uniform amounts-mostly a few or a few tens of parts per million-and show no marked relation to vanadium in their variation (for example, As, Be, Co, Dy, Er, Eu, Ga, Gd, Hg, Ho, Mn, $\mathrm{Pb}, \mathrm{Pr}, \mathrm{Re}, \mathrm{Sc}, \mathrm{Sm}, \mathrm{Ti}, \mathrm{Y}, \mathrm{Yb}$, and $\mathrm{Zr}$ ), but several other elements do seem to follow vanadium in concentration variations (for example, $\mathrm{Ag}, \mathrm{Cd}, \mathrm{Cr}, \mathrm{Mo}, \mathrm{Ni}, \mathrm{Se}, \mathrm{Sn}(?)$, $\mathrm{Tl}$, and $\mathrm{Zn}$ ). The distribution of the highest values does not correspond exactly, however. For example, although beds $\mathrm{P}-142$ and $\mathrm{P}-143$ contain the most $\mathrm{V}$ and the most $\mathrm{Ag}, \mathrm{Cu}$, and $\mathrm{Sn}$ as well, bed P-151 contains the most $\mathrm{Cd}, \mathrm{Mo}, \mathrm{Ni}$, and $\mathrm{Tl}$ and by far the most $\mathrm{Zn}$; bed P-154 contains the most Se by far; bed P-156 contains as much $\mathrm{Cu}$ as bed P-142 and more $\mathrm{Cr}$ than all other beds.

Table 11 shows estimates of the average and maximum contents of minor elements concentrated in the vanadiferous zone in amounts that are more than 10 times their averages in continental crust. The average concentration factors of $\mathrm{Cd}, \mathrm{Mo}, \mathrm{Se}, \mathrm{Ag}, \mathrm{Tl}, \mathrm{V}$, and $\mathrm{Zn}$ are greater than 30 ; $\mathrm{Cd}, \mathrm{Sc}$, and $\mathrm{Ag}$ show exceptionally high concentration factors of 2,350 , 11,000 , and 230 , respectively. The maximum concentration factors of $\mathrm{Cd}$ and Se are more than twice these average values, and maximum values for Mo, Tl, $\mathrm{V}$, and $\mathrm{Zn}$ are hundreds of times larger than their averages in continental crust.

Earth Sciences, Inc., which did some experimental mining in Bloomington Canyon in the 1970's, reported that the vanadiferous shale bed there averaged $4.1 \mathrm{ft}$ thick and contained 1.0 percent $\mathrm{V}_{2} \mathrm{O}_{5}, 13.7$ percent $\mathrm{P}_{2} \mathrm{O}_{5}, 0.0115$ percent $\mathrm{U}_{3} \mathrm{O}_{8}, 0.0225$ percent Se, 0.05 percent Mo, 3.6 percent $S, 20.1$ percent $C, 0.6$ percent $\mathrm{H}, 0.6$ percent $\mathrm{N}, 18.8$ percent $\mathrm{CaO}, 13.8$ percent $\mathrm{SiO}_{2}$, 4.3 percent $\mathrm{Al}_{2} \mathrm{O}_{3}, 2.0$ percent combined $\mathrm{H}_{2} \mathrm{O}, 8.0$ percent free $\mathrm{H}_{2} \mathrm{O}, 13.3$ percent undetermined, and 37.7 percent loss on ignition (De Voto and Stevens, 1979). The uranium content, as well as the phosphate content, is much higher than it is in the vanadiferous zone in western Wyoming.

\section{EFFECTS OF WEATHERING ON THE VANADIFEROUS ZONE}

The effects of Holocene weathering on rocks of the vanadiferous zone have been relatively minor. They involve partial oxidation of organic matter and pyrite, some leaching of carbonate and a consequent enrichment of phosphate, a change in color from black to dark brown, formation of orange coatings on joints, a change (in hardness) from hard to soft, and a change from massive to thin bedded or fissile. As we mentioned for the Sublette Ridge deposits, such weathering does not appear to have mobilized the vanadium. Weathering in phosphatic beds has caused an increase in phosphate that is proportional to a decrease in carbonate and organic matter; because much of the 
TABLE 7.-Partial composition (in wt percent) of the vanadiferous zone and adjacent beds in the Paris-Bloomington area, Idaho

[Analyses made under the direction of N. Herz, Homestake Mining Co. AI, acid insoluble; LOI, loss on ignition; sp. gr., specific gravity; N, none; tr, trace; --, not present; ?, presence uncertain; no entry, not analyzed]

\begin{tabular}{|c|c|c|c|c|c|c|c|c|c|}
\hline & \multicolumn{2}{|c|}{ Parisadit } & \multicolumn{2}{|c|}{ Paris wunze } & \multirow{2}{*}{$\begin{array}{l}\text { Northern drift. } \\
\text { Conwolidated } \\
\text { mine, no } \\
\mid x \text { x-cut }\end{array}$} & \multicolumn{2}{|c|}{$\begin{array}{l}\text { 14 South } \\
\text { incline }\end{array}$} & \multirow{2}{*}{$\begin{array}{l}\text { If South } \\
\text { incline. } \\
\text { 9oi fit } \\
\text { in }\end{array}$} & \multirow[b]{2}{*}{ Average $^{1}$} \\
\hline & Portal & $\begin{array}{c}259 \\
\mathrm{ft} \\
\mathrm{in}\end{array}$ & $\begin{array}{c}144 \\
\mathrm{ft} \\
\text { down }\end{array}$ & $\begin{array}{c}2112 \\
\mathrm{ft} \\
\text { down }\end{array}$ & & $\begin{array}{l}40 \mathrm{ft} \\
\text { in }\end{array}$ & $\begin{array}{c}73 \mathrm{ft} \\
\text { in }\end{array}$ & & \\
\hline \multicolumn{10}{|c|}{ Phosphatic sillstone } \\
\hline $\begin{array}{l}\mathrm{V}_{2} \mathrm{O}_{5} \\
\mathrm{Ni}_{5} \\
\mathrm{CaO} \\
\mathrm{P}_{2} \mathrm{O}_{5} \\
\mathrm{Al}_{5} \\
\mathrm{LOI} \\
\text { "Apatite"2 } \\
\mathrm{CaCO}_{3}{ }^{3} \\
\mathrm{Sp} . \mathrm{gr} \text {. } \\
\end{array}$ & & $\begin{array}{c}0.34^{4} \\
23.8^{4} \\
15.1^{4} \\
20.9^{4} \\
20.5 \\
39.3^{4} \\
6.9^{4} \\
2.70^{4} \\
\end{array}$ & $\begin{array}{c}0.14 \\
\\
30.0 \\
10.8 \\
24.0 \\
24.6 \\
28.1 \\
28.0 \\
2.71 \\
\end{array}$ & & $\begin{array}{c}049^{4} \\
.01^{4} \\
15.4^{4} \\
13.0^{4} \\
51.7^{4} \\
10.0^{4} \\
33.8^{4} \\
. .4 \\
2.52^{4}\end{array}$ & & $\begin{array}{c}0.17 \\
31.5 \\
26.7 \\
16.0 \\
11.8 \\
68.9 \\
2.80 \\
\end{array}$ & & $\begin{array}{c}0.28 \\
25.2 \\
16.4 \\
28.1 \\
16.7 \\
42.5 \\
\\
2.68\end{array}$ \\
\hline \multicolumn{10}{|c|}{ Sillutone } \\
\hline $\begin{array}{l}\mathrm{V}_{2} \mathrm{O}_{5} \\
\mathrm{Ni}_{5} \\
\mathrm{CaO}_{2} \\
\mathrm{P}_{2} \mathrm{O}_{5} \\
\mathrm{Al} \\
\text { LOI } \\
\text { "Apatite" } \\
\mathrm{CrCO}_{3} \\
\text { Sp. gr. }\end{array}$ & & $\begin{array}{c}0.86 \\
\mathrm{~N}^{4} \\
5.6 \\
3.4 \\
65.4 \\
19.9 \\
8.8 \\
2.0 \\
2.31\end{array}$ & $\begin{array}{c}0.65 \\
\operatorname{tr}^{4} \\
9.0 \\
3.3 \\
58.1 \\
21.1 \\
8.6 \\
8.2 \\
2.23\end{array}$ & $\begin{array}{c}05 x^{4} \\
N^{4} \\
67^{4} \\
54 \\
56.8^{4} \\
201^{4} \\
13^{4} \\
10.7^{4} \\
2.13^{4}\end{array}$ & $\begin{array}{c}10.9 .3 \\
3.7 \\
3.3 \\
60.1 \\
24.9 \\
8.6 \\
-. \\
2.16\end{array}$ & $\begin{array}{c}0.6 x \\
67 \\
40 \\
5 \times 7 \\
22.6 \\
104 \\
25 \\
2.22\end{array}$ & $\begin{array}{c}0.93 \\
\mathrm{~N}^{4} \\
3.7 \\
3.3 \\
5.4 .4 \\
28.8 \\
8.6 \\
-. \\
2.11\end{array}$ & & $\begin{array}{r}0.78 \\
\\
5.9 \\
2.9 \\
59.7 \\
22.9 \\
7.7 \\
\\
2.19\end{array}$ \\
\hline \multicolumn{10}{|c|}{ Phosphorite } \\
\hline $\begin{array}{l}\mathrm{V}_{2} \mathrm{O}_{5} \\
\mathrm{Ni}^{2} \\
\mathrm{CaO}_{2} \\
\mathrm{P}_{2} \mathrm{O}_{5} \\
\mathrm{Al} \\
\text { LOI } \\
\text { "Apatite" } \\
\mathrm{CaCO}_{3} \\
\mathrm{Sp} .8 \mathrm{gr} .\end{array}$ & $\begin{array}{c}0.45 \\
\\
38.2 \\
29.1 \\
14.2 \\
5.7 \\
75.7 \\
\ddot{-} \\
2.94\end{array}$ & $\begin{array}{c}0.51 \\
N \\
38.8 \\
25.8 \\
200 \\
10.3 \\
67.08 \\
? \\
2.72\end{array}$ & $\begin{array}{c}0.38 \\
\operatorname{tr} \\
32.6 \\
20.6 \\
22.4 \\
13.6 \\
5.3 .6 \\
7 \\
2.50\end{array}$ & $\begin{array}{c}0.42 \\
\\
25.6 \\
195 \\
29.4 \\
13.4 \\
507 \\
. . \\
266\end{array}$ & $\begin{array}{c}0.49 \\
t r \\
20.7 \\
23.4 \\
21.6 \\
111.2 \\
6118 \\
. . \\
2.611\end{array}$ & $\begin{array}{c}0.37 \\
25.4 \\
244 \\
17.4 \\
14.4 \\
63.4 \\
2.62 \\
2.62\end{array}$ & $\begin{array}{c}0.55 \\
\\
28.4 \\
22.1 \\
19.1 \\
19.2 \\
57.5 \\
.- \\
2.34\end{array}$ & $\begin{array}{c}0.50 \\
\\
27.8 \\
23.0 \\
19.6 \\
13.6 \\
59.8 \\
. .0 \\
2.77\end{array}$ & $\begin{array}{c}0.46 \\
29.7 \\
23.5 \\
20.6 \\
12.6 \\
61.1 \\
\\
2.64\end{array}$ \\
\hline \multicolumn{10}{|c|}{ Shale } \\
\hline $\begin{array}{l}\mathrm{V}_{2} \mathrm{O}_{5} \\
\mathrm{Ni}_{5} \\
\mathrm{CaO}_{2} \\
\mathrm{P}_{2} \mathrm{O}_{5} \\
\mathrm{Al}_{5} \\
\text { LOI } \\
\text { "Apatite" } \\
\mathrm{CsCO}_{3} \\
\mathrm{Sp} . \mathrm{gr} \text {. }\end{array}$ & $\begin{array}{c}1.68 \\
15.1 \\
11.9 \\
40.2 \\
17.4 \\
30.9 \\
. . \\
2.37\end{array}$ & $\begin{array}{c}1.06 \\
.017 \\
18.5 \\
12.3 \\
24.6 \\
35.3 \\
32.0 \\
-\quad 4.1 \\
-\quad 2.13 \\
\end{array}$ & $\begin{array}{c}0.96 \\
34^{4} \\
26.6 \\
7.7 \\
17.0 \\
34.9 \\
20.0 \\
29.3 \\
2.07\end{array}$ & $\begin{array}{c}1.01 \\
\text { tr } \\
217 \\
111 \\
1.91 \\
34.7 \\
26.3 \\
15.0 \\
2.13\end{array}$ & $\begin{array}{c}1.32 \\
11.2 \\
16.5 \\
11.19 \\
25.0 \\
3 \times 5 \\
286 \\
4.1 \\
1.93 \\
\end{array}$ & $\begin{array}{c}10.87 \\
22.8 \\
17.2 \\
21.3 \\
27.7 \\
14.7 \\
. .24 \\
2.24\end{array}$ & $\begin{array}{c}138 \\
t r \\
1 \times .2 \\
14.5 \\
211.3 \\
37.2 \\
37.7 \\
.7 \\
1.91\end{array}$ & $\begin{array}{c}1.37 \\
.02 \\
22.1 \\
16.5 \\
17.2 \\
24.6 \\
42.9 \\
.6 \\
2.31 \\
\end{array}$ & $\begin{array}{r}1.21 \\
.2 \\
12.6 \\
20.0 \\
32.5 \\
32.9 \\
2.14\end{array}$ \\
\hline \multicolumn{10}{|c|}{ Sillustone (ealcareoux and phoxphatic) } \\
\hline $\begin{array}{l}\mathrm{V}_{2} \mathrm{O}_{5} \\
\mathrm{C}_{20} \mathrm{O}^{2} \\
\mathrm{P}_{2} \mathrm{O}_{5} \\
\mathrm{Al}_{5} \\
\mathrm{LOI} \\
\text { "Apatite" " } \\
\mathrm{CaCO}_{3} \\
\text { Sp. gr. } \\
\end{array}$ & & $\begin{array}{c}0.15 \\
40.0 \\
2.2 \\
7.6 \\
41.3 \\
5.6 \\
66.4 \\
2.50 \\
\end{array}$ & $\begin{array}{c}0.15 \\
30.8 \\
4.2 \\
6.1 \\
42.8 \\
11.10 \\
45.11 \\
2.28 \\
\end{array}$ & & $\begin{array}{c}0.21 \\
2.41 \\
3.4 \\
6.4 \\
6.4 \\
4.3 .3 \\
9.9 \\
43.5 \\
2.30 \\
\end{array}$ & $\begin{array}{c}11.27 \\
21.1 \\
12.7 \\
9.8 \\
18.8 \\
3.1 .11 \\
7.7 \\
1.97 \\
\end{array}$ & $\begin{array}{c}0.60 \\
19.1 \\
14.9 \\
110.8 \\
47.2 \\
38.7 \\
.0 \\
1.91 \\
\end{array}$ & $\begin{array}{c}1.67 \\
18.0 \\
13.7 \\
22.5 \\
37.3 \\
33.6 \\
-.25 \\
2.25 \\
\end{array}$ & $\begin{array}{c}0.51 \\
26.4 \\
8.6 \\
10.5 \\
43.4 \\
22.3 \\
\\
2.20 \\
\end{array}$ \\
\hline \multicolumn{10}{|c|}{ Soft lenx in whale bed } \\
\hline $\begin{array}{l}\mathrm{V}_{2} \mathrm{O}_{5} \\
\mathrm{CaO} \\
\mathrm{P}_{2} \mathrm{O}_{5} \\
\mathrm{AI} \\
\text { LOI } \\
\text { "Apatite" } \\
\mathrm{CaCO}_{3} \\
\mathrm{Sp} . \mathrm{gr} \text {. }\end{array}$ & & $\begin{array}{c}1.20 \\
17.8 \\
10.7 \\
25.4 \\
34.3 \\
27.8 \\
6.6 \\
2.12 \\
\end{array}$ & & & & & $\begin{array}{c}0.96 \\
5.6 \\
6.2 \\
132 \\
69.4 \\
161 \\
-. \\
1.55 \\
\end{array}$ & & $\begin{array}{r}1.08 \\
11.7 \\
8.4 \\
19.3 \\
51.8 \\
21.9 \\
1.84 \\
\end{array}$ \\
\hline \multicolumn{10}{|c|}{ Hard lens in shale bed } \\
\hline $\begin{array}{l}\mathrm{V}_{2} \mathrm{O}_{5} \\
\mathrm{CsO}_{5} \\
\mathrm{P}_{2} \mathrm{O}_{5} \\
\mathrm{AI} \\
\mathrm{LOI} \\
\text { "Apatite" } \\
\mathrm{CaCO}_{3} \\
\mathrm{Sp} \text { gr. }\end{array}$ & & $\begin{array}{c}0.29 \\
26.6 \\
4.2 \\
5.6 \\
44.0 \\
10.8 \\
38.0 \\
2.41 \\
\end{array}$ & & & $\begin{array}{c}10.29 \\
25.8 \\
2.7 \\
3.5 \\
+4.8 \\
7.1 \\
39.6 \\
2.42\end{array}$ & & & & $\begin{array}{c}0.29 \\
26.3 \\
3.4 \\
4.5 \\
44.4 \\
8.9 \\
38.8 \\
2.41 \\
\end{array}$ \\
\hline \multicolumn{10}{|c|}{ Soft lenx between phosphorite and siltextone beds } \\
\hline $\begin{array}{l}\mathrm{V}_{2} \mathrm{O}_{5} \\
\mathrm{CaO} \\
\mathrm{P}_{2} \mathrm{O}_{5} \\
\mathrm{AI}_{5} \\
\text { LOI } \\
\text { "Apatite" } \\
\mathrm{CaCO}_{3} \\
\mathrm{Sp} . \mathrm{gr} \text {. }\end{array}$ & & & & & $\begin{array}{c}10.99 \\
24.8 \\
7.6 \\
1.1 .1 \\
32.3 \\
19.8 \\
26.4 \\
2.37\end{array}$ & & & & $\begin{array}{c}0.99 \\
24.8 \\
7.6 \\
18.1 \\
32.3 \\
19.8 \\
26.4 \\
2.3\end{array}$ \\
\hline
\end{tabular}

1 Average of analyses show $n$ in this table.

2. Apatite" here is assumed to be $\left.10 \mathrm{CaO}_{3} \cdot 3 \mathrm{P}_{2} \mathrm{O}\right)_{5} \cdot \mathrm{C}^{\circ} \mathrm{O}_{2} \cdot \mathrm{CaF}_{2}$. The amounts of "apatite" and $\mathrm{CaCO}_{3}$ shown are calculated by converting all the $\mathrm{P}_{2} \mathrm{O}_{5}$ to "apatite." adding the $\mathrm{CaO}$ necessary to satisfy the $\mathrm{P}_{2} \mathrm{O}_{5}$ and $\mathrm{F}$, and copverting the remaining ( $\mathrm{C}$ (O) to $\mathrm{Ca}(\mathrm{C})$

${ }^{3}$ Insufficient ("aO present to satisfy' the proportions called for in the "apatite" formula.

${ }^{4}$ Sample from only part of the bed. 
TABLE 8.-Partial chemical analyses (in wt percent) of the vanadiferous beds in the Paris-Bloomington area, Idaho

[Analyses by the U.S. Bureau of Mines (Ravitz and others, 1947). LOI, loss on ignition; n.d., not determined]

\begin{tabular}{|c|c|c|c|c|c|}
\hline $\begin{array}{l}\text { Lot } \\
6-6^{1}\end{array}$ & $\begin{array}{c}\text { Lot } \\
6-10^{1}\end{array}$ & $\begin{array}{c}\text { Lot } \\
6-11^{2}\end{array}$ & $\begin{array}{c}\text { Lot } \\
6-12^{3}\end{array}$ & $\underset{6-13^{4}}{\text { Lot }}$ & $\begin{array}{c}\text { Paris } \\
\text { composite }\end{array}$ \\
\hline $\mathrm{V}_{2} \mathrm{O}_{5}$ & 1.17 & 0.86 & 0.49 & 1.60 & 0.69 \\
\hline $\mathrm{P}_{2} \mathrm{O}_{5}$ & 10.3 & 3.0 & 22.8 & 12.8 & 13.1 \\
\hline .... 23.8 & 30.2 & 45.4 & 16.8 & 15.0 & 23.4 \\
\hline $\mathrm{Fe}_{2} \mathrm{O}_{3} \ldots \ldots$ & 3.0 & 1.7 & 2.3 & 1.4 & 1.8 \\
\hline $\mathrm{Al}_{2} \mathrm{O}_{3}$ & 11.1 & 10.2 & 4.3 & 4.7 & 6.8 \\
\hline $\mathrm{CaO} \ldots$ & 12.6 & 3.6 & 30.2 & 17.4 & 17.4 \\
\hline $\mathrm{S}$ & 2.0 & 2.1 & 1.2 & 4.6 & 2.8 \\
\hline $\mathrm{CO}_{2} \ldots$ & .6 & .4 & .7 & .6 & .6 \\
\hline Organic C & 12.6 & 14.4 & 8.5 & 25.7 & 16.0 \\
\hline $\mathrm{MoO}_{3} \ldots .02$ & .02 & .02 & $<.01$ & .07 & .03 \\
\hline …........ 3 & .3 & .6 & .2 & .2 & n.d. \\
\hline 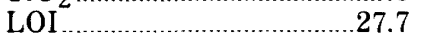 & 24.8 & 27.7 & 16.2 & 41.2 & 30.0 \\
\hline
\end{tabular}

1 Full thickness, Paris Canyon.

2 Unweathered siltstone bed, Paris Canyon winze.

3 Unweathered phosphorite bed, Paris Canyon winze.

${ }^{4}$ Unweathered shale bed, Paris Canyon winze.

5 Composite of lots 6-11, 6-12, and 6-13.

TABLE 9.-Partial chemical analyses (in wt percent) of vanadiferous beds in the Paris-Bloomington area, Idaho

[Analyses by the Anaconda Copper Mining Co. No entry, not analyzed]

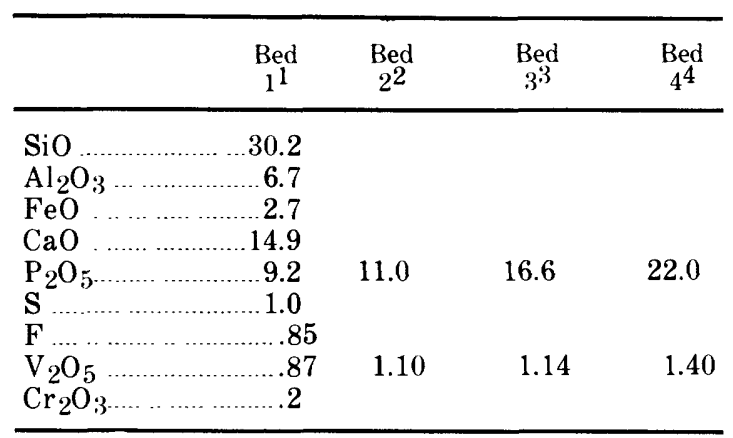

${ }^{1}$ Channel sample from full zone exposed in No. 2 Crosscut of Paris Canyon adit.

2 Calcined sample from bed 1 .

${ }^{3}$ Channel sample of shale and phosphorite beds $73 \mathrm{ft}$ from portal in 16 South incline.

${ }^{4}$ Calcined sample from bed 3 .

vanadium in such rocks is held in the apatite lattice, it locally shows slight increases (Lotspeich and Marquard, 1963).

A period of deep chemical weathering preceded the deposition of the Tertiary Wasatch Formation in the Paris-Bloomington area and elsewhere in the region. Near the erosion surface on which the Wasatch sediments were deposited, the rocks of the Meade Peak are light gray, tan, and pink, in contrast to their dark brown or black color elsewhere, and are similar in appearance to the burned rocks of the 14 South stockpiles. Weathering has removed calcium carbonate, organic matter, and vanadium, as well as part of the calcium from the apatite. This zone of leaching is exposed only in the trenches above the Consolidated mine in the Paris-Bloomington area and may extend to a depth of 150 to $175 \mathrm{ft}$ below the surface.

Enrichment of vanadium is found at or near the base of the zone of weathering. The rocks there are soft to medium hard and dark brown to black, and bedding planes are well defined. Visible occurrences of red hewettite $\left(\mathrm{CaO} \cdot 3 \mathrm{~V}_{2} \mathrm{O}_{5} \cdot 9 \mathrm{H}_{2} \mathrm{O}\right)$, green sincosite $\left(\mathrm{CaO} \cdot \mathrm{V}_{2} \mathrm{O}_{4} \cdot \mathrm{P}_{2} \mathrm{O}_{5} \cdot 5 \mathrm{H}_{2} \mathrm{O}\right)$, and orange pascoite $\left(2 \mathrm{CaO} \cdot 3 \mathrm{~V}_{2} \mathrm{O}_{5} \cdot 11 \mathrm{H}_{2} \mathrm{O}\right)$ are common. Locally, the hewettite forms tabular masses as much as a few inches thick and $2 \mathrm{ft}$ in diameter.

The enrichment in some places is considerable. The enriched part of the zone in the Consolidated mine contains 1.75 percent $\mathrm{V}_{2} \mathrm{O}_{5}$, in comparison with 0.79 percent $\mathrm{V}_{2} \mathrm{O}_{5}$ for unenriched rock (table 12). The enriched part of the shale bed in the 16 South incline contains 1.66 percent $\mathrm{V}_{2} \mathrm{O}_{5}$ in comparison with 1.38 percent $\mathrm{V}_{2} \mathrm{O}_{5}$ in the shale below the enriched zone. Elsewhere, the obvious secondary concentrations of vanadium are spotty, and the increase in average vanadium content is slight. Large masses of hewettite are present in the 14 South stopes, for example, but they are so irregularly distributed that the average $\mathrm{V}_{2} \mathrm{O}_{5}$ content of the "enriched" rock is only 0.06 percent more than that of the unenriched rock.

The limits of the obviously enriched zone are irregular, but, in the 14 and 16 South inclines, where it is 
TABLE 10.-Analyses of samples from the vanadiferous zone at Bloomington Canyon, Idaho (from Gulbrandsen, 1975; written communication, 1985)

[Organic matter analyzed by Don Krier; Ti, Hg, and N (total) by E. Campbell; Se by J.S. Wahlberg, J.O. Johnson, and R.J. Young; As by E.J. Fennelly; Re for beds P-143, P-150, P-151, P-154, P-155, and P-156 by Rowe and Steinnes (1976); emission spectrographic analyses for all other elements by J.D. Fletcher. See McKelvey and others (1953) for description of beds. n.d., not detected]

\begin{tabular}{|c|c|c|c|c|c|c|c|c|c|}
\hline $\begin{array}{c}\text { Bed } \\
\text { P-142 }\end{array}$ & $\begin{array}{c}\text { Bed } \\
\text { P-143 }\end{array}$ & $\begin{array}{c}\text { Bed } \\
\text { P-146 }\end{array}$ & $\begin{array}{c}\text { Bed } \\
\text { P-148 }\end{array}$ & $\begin{array}{c}\text { Bed } \\
\text { P-150 }\end{array}$ & $\begin{array}{c}\text { Bed } \\
\text { P.151 }\end{array}$ & $\begin{array}{c}\text { Bed } \\
\text { P.153 }\end{array}$ & $\begin{array}{c}\text { Bed } \\
\text { P-154 }\end{array}$ & $\begin{array}{c}\text { Bed } \\
\text { P-155 }\end{array}$ & $\begin{array}{c}\text { Bed } \\
\text { P-156 }\end{array}$ \\
\hline \multicolumn{10}{|c|}{ Amount, in wt percent } \\
\hline 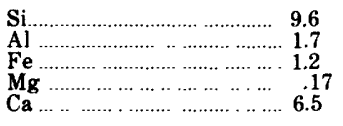 & $\begin{array}{c}12 \\
1.8 \\
.61 \\
.24 \\
7.9\end{array}$ & $\begin{array}{c}12 \\
2.6 \\
2.4 \\
.21 \\
19.5\end{array}$ & $\begin{array}{c}12 \\
1.8 \\
.68 \\
.14 \\
5.6\end{array}$ & $\begin{array}{c}28 \\
3.3 \\
2.4 \\
.24 \\
4.3\end{array}$ & $\begin{array}{l}35 \\
3.8 \\
2.5 \\
.25 \\
1.1\end{array}$ & $\begin{array}{c}38 \\
4.1 \\
1.5 \\
.37 \\
1.0\end{array}$ & $\begin{array}{c}>34 \\
\quad 4.4 \\
1.4 \\
.35 \\
1.2\end{array}$ & $\begin{array}{l}33 \\
3.9 \\
2.1 \\
.35 \\
3.2\end{array}$ & $\begin{array}{c}30 \\
3.6 \\
1.3 \\
.51 \\
3.5\end{array}$ \\
\hline 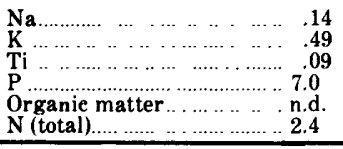 & $\begin{array}{r}>.3 \\
.55 \\
.11 \\
>6.8 \\
35.8 \\
2.1 \\
\end{array}$ & $\begin{array}{r}>.32 \\
.60 \\
>6.8 \\
>\text {..d. } \\
\text { n.d. } \\
.41 \\
\end{array}$ & $\begin{array}{r}.09 \\
.39 \\
.08 \\
6.2 \\
\text { n.d. } \\
1.0 \\
\end{array}$ & $\begin{array}{r}>.32 \\
1.2 \\
.22 \\
4.0 \\
21.0 \\
1.0 \\
\end{array}$ & $\begin{array}{r}>.32 \\
1.4 \\
1.26 \\
1.4 \\
22.9 \\
1.3 \\
\end{array}$ & $\begin{array}{l}.07 \\
1.7 \\
.28 \\
1.2 \\
\text { n.d. } \\
1.1 \\
\end{array}$ & $\begin{array}{r}.08 \\
1.4 \\
.28 \\
1.6 \\
24.2 \\
1.2 \\
\end{array}$ & $\begin{array}{r}.09 \\
1.4 \\
.30 \\
2.9 \\
24.4 \\
1.5 \\
\end{array}$ & $\begin{array}{r}.08 \\
1.4 \\
.24 \\
2.1 \\
18.1 \\
.70 \\
\end{array}$ \\
\hline \multicolumn{10}{|c|}{ Amount, in parts per million } \\
\hline 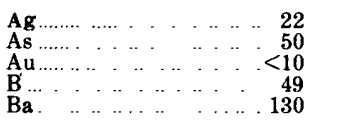 & $\begin{array}{r}22 \\
20 \\
<10 \\
140 \\
270\end{array}$ & $\begin{array}{r}14 \\
40 \\
<10 \\
68 \\
240\end{array}$ & $\begin{array}{r}16 \\
25 \\
<10 \\
25 \\
180\end{array}$ & $\begin{array}{r}14 \\
50 \\
<10 \\
130 \\
340\end{array}$ & $\begin{array}{r}12 \\
50 \\
<10 \\
140 \\
300\end{array}$ & $\begin{array}{r}14 \\
20 \\
<10 \\
190 \\
340\end{array}$ & $\begin{array}{r}14 \\
20 \\
<10 \\
190 \\
380\end{array}$ & $\begin{array}{r}16 \\
25 \\
<10 \\
200 \\
360\end{array}$ & $\begin{array}{r}16 \\
12 \\
<10\end{array}$ \\
\hline 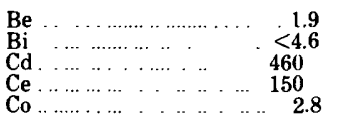 & $\begin{array}{l}2.9 \\
<4.6 \\
760 \\
<63 \\
\quad 2.3\end{array}$ & $\begin{aligned} & 3.3 \\
&<4.6 \\
& 420 \\
&<63 \\
& \quad 2.2\end{aligned}$ & $\begin{array}{c}2.4 \\
<4.6 \\
380 \\
99 \\
1.0\end{array}$ & $\begin{array}{c}3.7 \\
<4.6 \\
970 \\
130 \\
9.5\end{array}$ & $\begin{array}{l}2.3 \\
<4.6 \\
980 \\
110 \\
10\end{array}$ & $\begin{array}{c}<4 \\
<4.6 \\
170 \\
73 \\
2.6\end{array}$ & $\begin{array}{c}2.7 \\
<4.6 \\
180 \\
69 \\
3.5\end{array}$ & $\begin{array}{c}3.3 \\
<4.6 \\
170 \\
<63 \\
2.1\end{array}$ & $\begin{array}{c}2.9 \\
<4.6 \\
180 \\
130 \\
1.4\end{array}$ \\
\hline 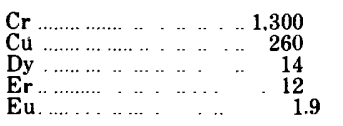 & $\begin{array}{c}1.500 \\
420 \\
14 \\
9.3 \\
2.5\end{array}$ & $\begin{array}{c}1.400 \\
99 \\
19 \\
10 \\
1.8\end{array}$ & $\begin{array}{c}860 \\
120 \\
9.8 \\
7.9 \\
1.9\end{array}$ & $\begin{array}{c}850 \\
180 \\
24 \\
27 \\
3.3\end{array}$ & $\begin{array}{c}940 \\
110 \\
17 \\
11 \\
3.5\end{array}$ & $\begin{array}{l}1.200 \\
180 \\
<6.8 \\
<4.6 \\
1.9\end{array}$ & $\begin{array}{l}980 \\
250 \\
8.7 \\
6.6 \\
1.6\end{array}$ & $\begin{array}{c}1.200 \\
170 \\
14 \\
8.7 \\
2.5\end{array}$ & $\begin{array}{r}1.600 \\
260 \\
7.8 \\
<4.6 \\
2.4\end{array}$ \\
\hline 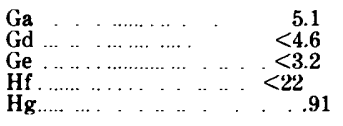 & $\begin{array}{r}9.8 \\
23 \\
<3.2 \\
<22 \\
\quad .94\end{array}$ & $\begin{array}{r}5.6 \\
<15 \\
<3.2 \\
<22 \\
\quad .60\end{array}$ & $\begin{array}{r}3.9 \\
<4.6 \\
<3.2 \\
<22 \\
1.3\end{array}$ & $\begin{array}{c}7.2 \\
18 \\
<3.2 \\
<22 \\
\quad .80\end{array}$ & $\begin{array}{r}8.9 \\
26 \\
<3.2 \\
<22 \\
\quad .78\end{array}$ & $\begin{array}{c}9.2 \\
19 \\
<3.2 \\
<22 \\
.86\end{array}$ & $\begin{array}{r}9.1 \\
23 \\
<3.2 \\
<22 \\
\quad .80\end{array}$ & $\begin{array}{r}8.2 \\
16 \\
<3.2 \\
<22 \\
1.6\end{array}$ & $\begin{array}{r}7.9 \\
<15 \\
<3.2 \\
<22 \\
1.1\end{array}$ \\
\hline 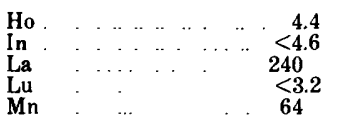 & $\begin{array}{c}3.7 \\
<4.6 \\
170 \\
<3.2 \\
66\end{array}$ & $\begin{array}{c}<3.2 \\
<4.6 \\
140 \\
<3.2 \\
120\end{array}$ & $\begin{array}{c}3.4 \\
<4.6 \\
130 \\
<3.2 \\
34\end{array}$ & $\begin{array}{l}\quad 6.7 \\
<4.6 \\
150 \\
<3.2 \\
140\end{array}$ & $\begin{array}{l}<3.2 \\
<4.6 \\
100 \\
<3.2 \\
270\end{array}$ & $\begin{array}{l}<3.2 \\
<4.6 \\
58 \\
<3.2 \\
79\end{array}$ & $\begin{array}{l}<3.2 \\
<4.6 \\
68 \\
<3.2 \\
98\end{array}$ & $\begin{array}{l}3.8 \\
<4.6 \\
96 \\
<3.2 \\
91\end{array}$ & $\begin{array}{l}<3.2 \\
<4.6 \\
90 \\
<3.2 \\
83\end{array}$ \\
\hline 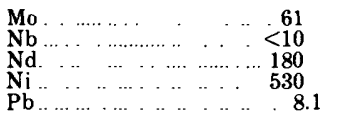 & $\begin{array}{r}44 \\
<10 \\
120 \\
410 \\
14\end{array}$ & $\begin{array}{r}33 \\
<10 \\
<68 \\
73 \\
11\end{array}$ & $\begin{array}{l}\quad 6.1 \\
<10 \\
<68 \\
120 \\
<6.8\end{array}$ & $\begin{array}{r}140 \\
<10 \\
<68 \\
340 \\
10\end{array}$ & $\begin{array}{r}280 \\
<10 \\
<68 \\
540 \\
14\end{array}$ & $\begin{array}{r}30 \\
<10 \\
<68 \\
180 \\
19\end{array}$ & $\begin{array}{r}22 \\
<10 \\
<68 \\
290 \\
11\end{array}$ & $\begin{array}{r}23 \\
<10 \\
<68 \\
150 \\
14\end{array}$ & $\begin{array}{c}<.6 \\
<10 \\
<68 \\
160 \\
13\end{array}$ \\
\hline 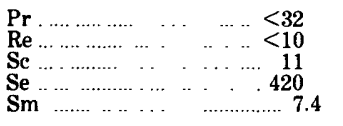 & $\begin{array}{c}<32 \\
3.6 \\
14 \\
820 \\
6.7\end{array}$ & $\begin{array}{c}22 \\
<10 \\
12 \\
21 \\
<4.6\end{array}$ & $\begin{array}{c}25 \\
<10 \\
10 \\
430 \\
6.3\end{array}$ & $\begin{array}{l}33 \\
3.9 \\
20 \\
440 \\
7.4\end{array}$ & $\begin{array}{c}26 \\
4.4 \\
17 \\
590 \\
7.6\end{array}$ & $\begin{array}{c}<32 \\
<10 \\
17 \\
480 \\
6.8\end{array}$ & $\begin{array}{c}<32 \\
4.9 \\
17 \\
1,200 \\
6.6\end{array}$ & $\begin{array}{c}<32 \\
5.8 \\
19 \\
940 \\
6.8\end{array}$ & $\begin{array}{c}25 \\
16 \\
420 \\
7.4\end{array}$ \\
\hline 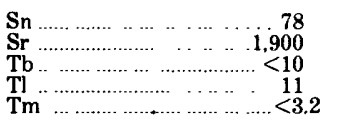 & $\begin{array}{c}100 \\
2,200 \\
<10 \\
15 \\
<3.2\end{array}$ & $\begin{array}{c}25 \\
1,500 \\
<10 \\
10 \\
<3.2\end{array}$ & $\begin{array}{c}32 \\
780 \\
<10 \\
\quad 7.1 \\
<3.2\end{array}$ & $\begin{array}{c}17 \\
460 \\
<10 \\
74 \\
2.9\end{array}$ & $\begin{array}{l}19 \\
370 \\
<10 \\
110 \\
<3.2\end{array}$ & $\begin{array}{c}32 \\
440 \\
<10 \\
26 \\
<3.2\end{array}$ & $\begin{array}{c}26 \\
470 \\
<10 \\
36 \\
<3.2\end{array}$ & $\begin{array}{r}28 \\
550 \\
<10 \\
36 \\
<3.2\end{array}$ & $\begin{array}{c}78 \\
1.900 \\
<10 \\
11 \\
3.3\end{array}$ \\
\hline 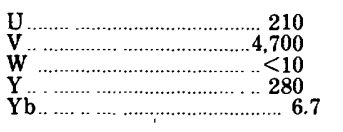 & $\begin{array}{c}<150 \\
>4,000 \\
<10 \\
140 \\
7.9\end{array}$ & $\begin{array}{r}<150 \\
1.700 \\
<10 \\
180 \\
16\end{array}$ & $\begin{array}{c}<150 \\
2,400 \\
<10 \\
220 \\
7.3\end{array}$ & $\begin{array}{r}<150 \\
2.900 \\
<10 \\
370 \\
14\end{array}$ & $\begin{array}{c}<150 \\
2,900 \\
<10 \\
140 \\
7.7\end{array}$ & $\begin{array}{c}<150 \\
4,100 \\
<10 \\
80 \\
4.3\end{array}$ & $\begin{array}{c}<150 \\
4,000 \\
<10 \\
95 \\
5.6\end{array}$ & $\begin{array}{c}<150 \\
3,000 \\
<10 \\
150 \\
7.2\end{array}$ & $\begin{array}{r}<150 \\
2,400 \\
<10 \\
130 \\
21\end{array}$ \\
\hline 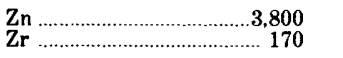 & $\begin{array}{r}1,400 \\
190\end{array}$ & $\begin{array}{l}620 \\
410\end{array}$ & $\begin{array}{l}580 \\
150\end{array}$ & $\begin{array}{r}4,700 \\
310\end{array}$ & $\begin{array}{r}10,000 \\
280\end{array}$ & $\begin{array}{l}490 \\
250\end{array}$ & $\begin{array}{r}1,600 \\
240\end{array}$ & $\begin{array}{l}380 \\
430\end{array}$ & $\begin{array}{l}360 \\
120\end{array}$ \\
\hline
\end{tabular}


TABLE 11.-Estimates of minor-element abundances in the vanadiferous zone at Bloomington Canyon, Idaho, in comparison with their average concentrations in continental crust (after Gulbrandsen, 1977)

\begin{tabular}{|c|c|c|c|c|c|}
\hline & \multicolumn{2}{|c|}{ Vanadiferous zone } & \multicolumn{2}{|c|}{ Continental crust } & \multirow[b]{2}{*}{$\begin{array}{c}\text { Concentration } \\
\text { factor } 1\end{array}$} \\
\hline & $\begin{array}{c}\text { No. of } \\
\text { Element }\end{array}$ & $\begin{array}{l}\text { Average, } \\
\text { samples }\end{array}$ & $\begin{array}{l}\text { Maximum, } \\
\text { in ppm }\end{array}$ & $\begin{array}{c}\text { Average, } \\
\text { in ppm }\end{array}$ & \\
\hline $\mathrm{As}^{2}$ & 10 & 30 & 50 & 1.8 & 17 \\
\hline $\mathrm{B}^{3} \ldots$ & 10 & 130 & 200 & 10 & 13 \\
\hline $\mathrm{Cd}^{3}$ & 10 & 470 & 980 & .2 & 2,350 \\
\hline $\mathrm{Cr}^{3}$ & 10 & 1,200 & 1,600 & 100 & 12 \\
\hline $\mathrm{Hg}^{4}$ & 10 & 1 & 1.6 & .08 & 12.5 \\
\hline $\mathrm{Mo}^{3}$ & 10 & 60 & 280 & 1.5 & 40 \\
\hline $\mathrm{Se}^{5}$ & 10 & 560 & 1,200 & .05 & 11,000 \\
\hline $\mathrm{Ag}^{3}$ & 10 & 16 & 20 & .07 & 230 \\
\hline $\mathrm{Tl}^{4}$ & 10 & 40 & 110 & .45 & 89 \\
\hline $\mathrm{Sn}^{3}$ & 10 & 40 & 100 & 2 & 20 \\
\hline $\mathrm{V}^{6} \ldots$ & ..... 10 & 4,600 & 17,000 & $13 \overline{5}$ & 34 \\
\hline $\mathrm{Zn}$ & 10 & 2,400 & 10,000 & 70 & 34 \\
\hline
\end{tabular}

1 Ratio of vanadiferous zone average to continental crust average.

2 Spectrophotometric analysis by E.J. Fennelly.

3 Semiquantitative spectrographic analysis by J. Fletcher.

4 Analysis by E. Campbell.

5X-ray fluorescence analysis by J.S. Wahlberg, J.D. Johnson, and R.J. Young

6 Analysis by J. Fletcher and H.H. Lipp.

TABLE 12.-Comparison of the thicknesses and $V_{2} \mathrm{O}_{5}$ contents of partly leached, enriched, and unenriched rocks of the vanadiferous zone in the Paris-Bloomington area, Idaho

[No entry, not analyzed]

\begin{tabular}{|c|c|c|c|c|c|c|c|c|}
\hline & \multicolumn{2}{|c|}{ Partly leached rock } & \multicolumn{2}{|c|}{ Enriched rock } & \multicolumn{2}{|c|}{ Unenriched rock } & \multicolumn{2}{|c|}{ Average } \\
\hline & $\begin{array}{c}\text { Thickness, } \\
\text { in } \mathrm{ft}\end{array}$ & $\frac{\mathrm{V}_{2} \mathrm{O}_{5}}{\text { in percent }}$ & $\begin{array}{c}\text { Thickness, } \\
\text { in } \mathrm{ft}\end{array}$ & $\begin{array}{c}\mathrm{V}_{2} \mathrm{O}_{5}, \\
\text { in percent }\end{array}$ & $\begin{array}{c}\text { Thickness, } \\
\text { in } \mathrm{ft}\end{array}$ & $\begin{array}{c}\mathrm{V}_{2} \mathrm{O}_{5}, \\
\text { in percent }\end{array}$ & $\begin{array}{l}\text { Thickness, } \\
\text { in } \mathrm{ft}\end{array}$ & $\begin{array}{c}\mathrm{V}_{2} \mathrm{O}_{5} \\
\text { in percent }\end{array}$ \\
\hline \multicolumn{9}{|c|}{ Consolidated mine } \\
\hline $\begin{array}{l}\text { Siltstone } \\
\text { Phosphorite } \\
\text { Shale ........................... } \\
\quad \text { Total }\end{array}$ & . & . & $\begin{array}{l}3.5^{1} \\
\ldots .4^{1} \\
\ldots .2 .9^{1} \\
7.8\end{array}$ & $\begin{array}{l}1.50^{1} \\
.74^{1} \\
1.89^{1,2} \\
1.75^{3}\end{array}$ & $\begin{array}{c}4.7^{4} \\
2.8^{4} \\
3.4^{4} \\
10.9\end{array}$ & $\begin{array}{r}0.67^{4} \\
.49^{4} \\
1.22^{4} \\
.79^{3}\end{array}$ & $\begin{array}{l}4.4 \\
2.1 \\
3.3 \\
9.8\end{array}$ & $\begin{array}{c}0.94 \\
.57 \\
1.45 \\
1.03^{3}\end{array}$ \\
\hline \multicolumn{9}{|c|}{16 South incline } \\
\hline Shale $^{5}$ & $3.3^{6}$ & $1.26^{6}$ & $5.2^{7}$ & $1.66^{7}$ & $4.1^{8}$ & $1.38^{8}$ & 4.1 & 1.40 \\
\hline \multicolumn{9}{|c|}{14 South incline } \\
\hline Shale ............... & $\ldots \ldots .3 .4$ & 1.11 & 3.9 & 1.37 & 3.8 & 1.31 & 3.6 & 1.29 \\
\hline
\end{tabular}

1Sampled along $180 \mathrm{ft}$ of drift.

Includes siltstone bed below shale where enriched 45 to $140 \mathrm{ft}$ north of No. 1 crosscut.

${ }^{3}$ Weighted average.

4 Sampled along $283 \mathrm{ft}$ of drift.

5 Includes siltstone below shale 85 to $175 \mathrm{ft}$ from portal.

6 Sampled along $85 \mathrm{ft}$ of incline.

7 Sampled along $45 \mathrm{ft}$ of incline.

8 Sampled along $150 \mathrm{ft}$ of incline. 
defined by the presence of hewettite, the zone extends downdip for 40 to $50 \mathrm{ft}$. In the northern drift of the Consolidated mine, where the rocks are faulted and broken, ennrichment extends to still greater depths. Differences in permeability of the individual beds also affect the depth of weathering and consequent enrichment. The phosphorite bed, for example, is commonly weathered to greater depths than the other beds are.

Enrichment in the Bloomington Canyon workings is almost entirely restricted to the shale bed and to the beds below it that are only weakly vanadiferous elsewhere. This restriction suggests that solutions migrating downward along the shale bed locally departed from it and moved downward into the underlying beds along steeply dipping fractures. In the northern drift of the Consolidated mine, where the rocks dip $50^{\circ}$ to $60^{\circ} \mathrm{W}$., all of the exposed beds are locally enriched, an indication that solutions there worked downward mainly along bedding planes but locally departed from them along fractures to enter either hanging-wall or footwall beds. Local lenses, particularly those between the phosphorite and siltstone beds, are strikingly enriched in places. Weathering apparently removed the calcite from these lenses and left a spongy mass favorable for the deposition of secondary minerals.

The rocks below the zone of enrichment are hard, black, and in places contain pyrite and white coatings on fractures and joints. Sincosite is found locally below the zone of enrichment in the Bloomington Canyon workings but is of no quantitative importance. The lenses and siltstone beds below the shale are calcareous in the Consolidated mine, but the beds of the vanadiferous zone there are only weakly calcareous. All the rocks in the bottom of the Paris Canyon winze, however, are calcareous, and the $\mathrm{V}_{2} \mathrm{O}_{5}$ content of the zone as a whole is only about 0.6 percent, in contrast to the average of 0.9 percent elsewhere in the mine.
Because the vanadium content of calcareous rocks from the bottom of the winze is lower than that of rocks elsewhere in the mine, samples from other workings may not be reliable indicators of the grade of the zone in deeper parts of the syncline, since the so-called unenriched rocks may in fact be somewhat enriched, even though they contain no visible signs of enrichment. Should this scenario prove true, the grade of the zone at depth might be more comparable to that near the base of the winze than to the higher values in the other workings.

\section{VARIATIONS IN THICKNESS AND VANADIUM CONTENT OF THE VANADIFEROUS ZONE}

The thicknesses and vanadium contents of the beds of the vanadiferous zone vary considerably in individual samples, although averages of groups of samples generally differ only slightly. However, some lateral variations, due chiefly to weathering, can be observed.

As table 13 shows, the beds on the normal limb of the syncline are about 20 percent thicker than those on the overturned limb. The siltstone and phosphorite beds on the normal limb are somewhat less vanadiferous.

The vanadiferous zone as a whole contains less than average amounts of vanadium in the apparently unaltered part of the Consolidated mine, owing to the presence of abundant, weakly vanadiferous calcareous lenses. These lenses also add to the thickness of the zone, making it somewhat thicker than it is elsewhere on the overturned limb (compare tables 13 and 14).

The most conspicuous differences in grade and thickness are between individual samples, as table 15 shows. Extreme differences in thickness occur on the overturned limb; differences in the vanadium contents of these rocks reflect the effects of leaching and enrichment.

TABLE 13.-Comparison of the thicknesses and canadium contents of the canadiferous beds on the normal and overturned limbs of the Paris syncline. Idaho

\begin{tabular}{|c|c|c|c|c|c|c|}
\hline & \multicolumn{2}{|c|}{ Normal limb1 } & \multicolumn{2}{|c|}{ Overturned limb ${ }^{\mathrm{l}}$} & \multicolumn{2}{|c|}{ Average } \\
\hline & $\begin{array}{c}\mathrm{V}_{2} \mathrm{O}_{5}, \\
\text { in percent }\end{array}$ & $\begin{array}{l}\text { Thickness, } \\
\text { in } \mathrm{ft}\end{array}$ & $\begin{array}{c}\mathrm{V}_{2} \mathrm{O}_{5} \\
\text { in percent }\end{array}$ & $\begin{array}{c}\text { Thickness, } \\
\text { in } \mathrm{ft}\end{array}$ & $\begin{array}{c}\mathrm{V}_{2} \mathrm{O}_{5} \\
\text { in percent }\end{array}$ & $\begin{array}{l}\text { Thickness, } \\
\text { in } \mathrm{ft}\end{array}$ \\
\hline Siltstone & $\ldots .0 .82$ & 4.9 & 0.89 & 4.0 & 0.85 & 4.5 \\
\hline Phosphorite & $\ldots \ldots .43$ & 2.5 & .61 & 2.1 & .51 & 2.3 \\
\hline \multirow[t]{2}{*}{ Shale $^{2}$} & $\ldots .1 .36$ & 3.8 & 1.35 & 3.1 & 1.36 & 3.4 \\
\hline & .92 & 11.2 & .98 & 9.2 & .95 & 10.2 \\
\hline
\end{tabular}

1 Based on samples obtained in underground workings only.

2 Includes siltstone bed below shale where it is high grade in the Consolidated mine and 16 South incline. 
PARIS-BLOOMINGTON DEPOSITS

TABLE 14.-Effect of lenses on the unaltered vanadiferous zone in the Consolidated mine, Paris-Bloomington area, Idaho

\begin{tabular}{|c|c|c|c|c|c|c|}
\hline \multirow[b]{2}{*}{ Bed } & \multicolumn{2}{|c|}{ With lenses } & \multicolumn{2}{|c|}{ Without lenses } & \multicolumn{2}{|c|}{ Lenses only } \\
\hline & $\begin{array}{c}\text { Thickness, } \\
\text { in } \mathrm{ft}\end{array}$ & $\begin{array}{c}\mathrm{V}_{2} \mathrm{O}_{5} \\
\text { in percent }\end{array}$ & $\begin{array}{l}\text { Thickness, } \\
\text { in } \mathrm{ft}\end{array}$ & $\begin{array}{c}\mathrm{V}_{2} \mathrm{O}_{5}, \\
\text { in percent }\end{array}$ & $\begin{array}{c}\text { Thickness, } \\
\text { in } \mathrm{ft}\end{array}$ & $\begin{array}{c}\mathrm{V}_{2} \mathrm{O}_{5} \\
\text { in percent }\end{array}$ \\
\hline Siltstone & $\ldots . .8$ & 0.67 & 4.5 & 0.68 & 1.1 & 0.48 \\
\hline Phosphorite & 2.8 & .49 & 2.2 & .55 & 1.4 & .26 \\
\hline Shale & $\ldots .3 .3$ & 1.22 & 2.7 & 1.40 & 2.4 & .30 \\
\hline All beds & $\ldots 10.9$ & .86 & 9.4 & 1.22 & 4.9 & .33 \\
\hline
\end{tabular}

TABLE 15.-Range in thickness and grade of the vanadiferous zone in the Paris-Bloomington area, Idaho

\begin{tabular}{|c|c|c|c|c|}
\hline & \multicolumn{2}{|c|}{ Range of local averages 1} & \multicolumn{2}{|c|}{ Extreme ranges 2} \\
\hline & $\begin{array}{l}\text { Thickness, } \\
\text { in } \mathrm{ft}\end{array}$ & $\begin{array}{l}\mathrm{V}_{2} \mathrm{O}_{5} \text { content. } \\
\text { in percent }\end{array}$ & $\begin{array}{l}\text { Thickness, } \\
\text { in } \mathrm{ft}\end{array}$ & $\begin{array}{l}\mathrm{V}_{2} \mathrm{O}_{5} \text { content. } \\
\text { in percent }\end{array}$ \\
\hline Siltstone & $. .3 .7-5.2$ & $0.72-0.98$ & $1.1-6.9$ & $0.06-2.43$ \\
\hline Phosphorit & $2.0-3.0$ & $.39-.67$ & $.5-4.7$ & $.08-2.43$ \\
\hline Shale & $\ldots 2.9-4.1$ & $.84-1.05$ & $.05-7.2$ & $.06-5.73^{3}$ \\
\hline Full zone... & $\ldots 8.8-11.8$ & $.84-1.05$ & $5.8-16.1$ & $.07-1.80$ \\
\hline
\end{tabular}

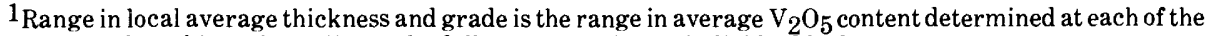
underground workings; it applies to the full zone as well as to individual beds.

2 Extreme range in thickness and grade is the range in individual samples of the bed. For the full zone, it is the range in complete sections of the three beds.

${ }^{3}$ Includes siltstone bed $\left(0.6 \mathrm{ft}\right.$ thick) below the shale, which contains 23.00 percent $\mathrm{V}_{2} \mathrm{O}_{5}$ at this point.
}

The distribution of vanadium within each bed is generally uniform. Sections of the vanadiferous zone in which the thinnest recognizable units of each bed were sampled separately show that the vanadium content of the siltstone is remarkably constant from top to bottom, that the siltstone layers of the phosphorite bed contain more vanadium than the phosphatic ones, and that the upper phosphatic and lower blocky parts of the overlying shale bed contain slightly less vanadium than the central part of the bed.

\section{RESOURCES}

The tonnages, stratigraphic distributions, and vanadium contents of the vanadiferous beds-classed as measured, indicated, and inferred subeconomic resources-are summarized in table 16 . If the tonnage were projected to the northern end of the area mapped, it would be approximately tripled.

Estimates were made of the shale bed separately because of its much higher grade; of the shale and the phosphorite, in case it should prove impractical to mine the full zone; and of the full zone. The Wyodak Coal and Manufacturing Co. did not undertake experimental mining of the shale bed alone, but it did successfully complete experimental mining of the other two units in the 14 South workings on the normal limb of the syncline by the longwall mining method. Although no experimental mining was attempted on the overturned limb, operations manager J.D. Johnson believed that the top-slicing method of mining would be suitable for that part of the deposit.

Although some possible means of vanadium recovery have been identified (Ravitz and others, 1947; De Voto and Stevens, 1979), the commercial feasibility of production from the zone has not been demonstrated, and its resources are considered subeconomic for the present. They are classed as measured where the vanadiferous beds are known to be present, and their thicknesses and vanadium contents have been well established by taking closely spaced samples and measurements. The limits of error in these estimates are judged not to exceed 15 percent. Resources have been measured in the Paris Canyon area, where the zone was sampled in $725 \mathrm{ft}$ of underground workings, four trenches, and one short crosscut; in the Consolidated mine area, where the zone was sampled in nearly $500 \mathrm{ft}$ of underground workings; and in Bloomington Canyon, between the 12 South adit and 16 South incline, where the zone was sampled in 
TABLE 16.-Subeconomic vanadium resources in the Paris-Bloomington area, Idaho

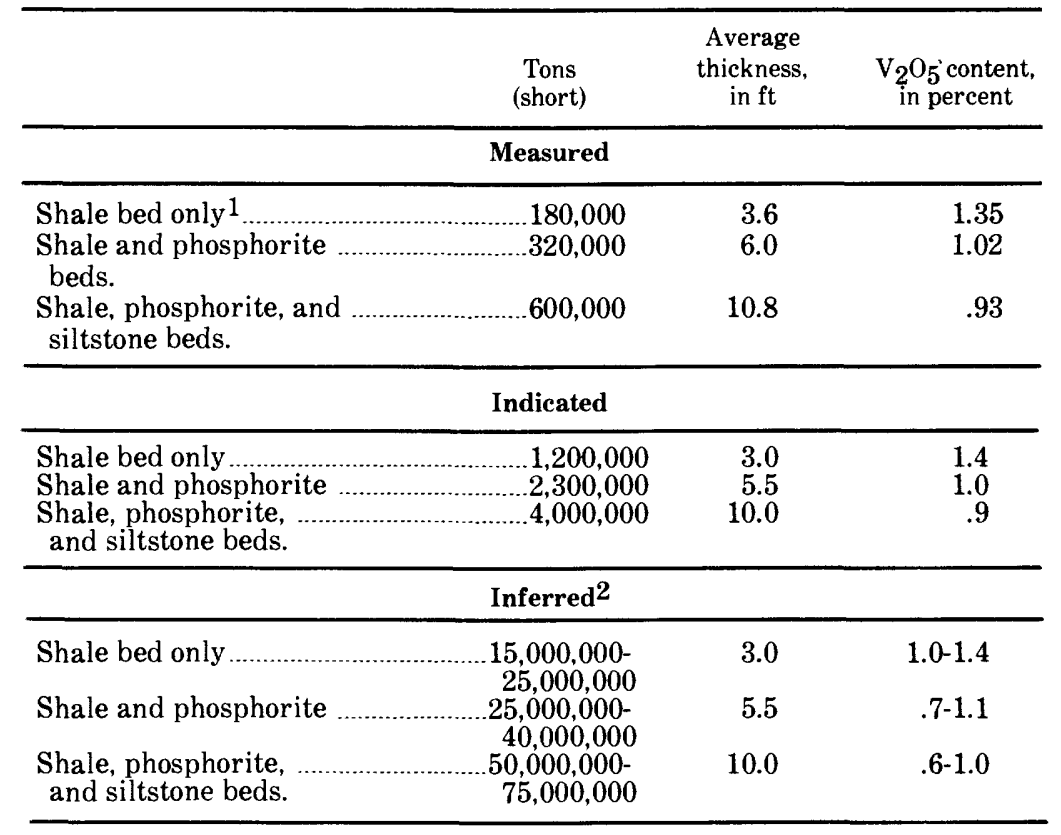

\footnotetext{
1 Siltstone below shale included where it is enriched in Consolidated mine and 16 South incline.

${ }^{2}$ Inferred resources stated for area south of northernmost intersection of zone in Paris Canyon.
}

nearly $1,200 \mathrm{ft}$ of underground workings. The measured resources lie above a depth of $200 \mathrm{ft}$ below drainage level.

In areas between or adjacent to those containing measured resources, the cover is such that the structural continuity of the zone is not well established, and samples and measurements are few and widely spaced. Resources in these areas-estimated partly on the basis of samples and measurements and partly on the basis of geologic projection from adjacent areasare classed as indicated.

Because the hard, calcareous rocks encountered in the bottom of the Paris Canyon winze may be typical of unaltered rock, the beds sampled in most of the workings may be slightly enriched and therefore not representative of the rocks at depth. Indicated resources are therefore limited only to the beds between the surface and the depth below the old Tertiary surface equivalent to the bottom of the winze. This elevation in Paris and Bloomington Canyons is about $6,000 \mathrm{ft}$, but, at the divide between the two, it is assumed to be about $6,250 \mathrm{ft}$.

Because the vanadiferous zone is faulted out at the surface north of trench 4 North (on the northern side of Paris Canyon), the existence of resources on the overturned limb is not certain enough to justify the estimation of any indicated resources there. There are no exposures east and north of the 16 South incline to define the extent of the zone on the normal limb. Since no evidence contradicts the reasonable assumption that the zone extends for some distance in this direction, resources extending $500 \mathrm{ft}$ east of the 16 South incline are arbitrarily classed as indicated.

The limits of inferred subeconomic resources are defined by the boundaries of the measured and indicated resources in the southern and southwestern parts of the area, by the supposed position of a possible fault along the eastern edge of the Paris syncline, and, arbitrarily, by the northernmost exposure of the zone in Paris Canyon. The Paris syncline is known to extend as far north as Liberty, about $7 \mathrm{mi}$ north of Paris Canyon, and it seems likely that the zone extends over the entire structure. For the purpose of this report, however, it is assumed that its northern limit corresponds to the northern limit of the area mapped, about $3.5 \mathrm{mi}$ north of Paris Canyon. As table 16 (footnote 2) states, if inferred resources were considered to extend to the latter limit, the estimates would be approximately triple those shown in the table. Most of the inferred resources lie above a depth of $3,500 \mathrm{ft}$ below drainage level.

The vanadium content of the greater part of the inferred resources may more nearly approximate that of the zone in the bottom of the Paris Canyon winze ( 0.6 percent $\mathrm{V}_{2} \mathrm{O}_{5}$ ) than that of the zone sampled in other workings $\left(0.9\right.$ percent $\left.\mathrm{V}_{2} \mathrm{O}_{5}\right)$. Even if this assumption 
is correct, part of these resources-those on the overturned limb of the syncline above an elevation of about $6,000 \mathrm{ft}$ and those northeast of the 16 South incline on the normal limb above an elevation of 5,800 to 6,000 $\mathrm{ft}$-should be comparable in grade to those of the measured and indicated resources. To emphasize the uncertainties caused by these factors, the tonnages and grades of the inferred resources are expressed as ranges in table 16.

To prepare these estimates, samples were weighted according to their abundance as well as to their area of influence. Thus, in determining the grade and thickness in a given block, the average of many samples from an underground working was given more weight than samples from individual trenches, even though the area of influence of the latter may have been greater. Because samples in the underground workings were rather uniformly spaced (about $10 \mathrm{ft}$ apart), averages were determined by weighting the samples by thickness but not by distance between them. Samples of part of a bed were not included. The beds differ in density, and, if units had been combined according to weight rather than volume alone, the average grade would differ by 0.02 to 0.03 percent $\mathrm{V}_{2} \mathrm{O}_{5}$. Because the discrepancy thus produced would have been small, weight was disregarded in calculating the average grades of the shale-phosphorite combination and the full zone.

The beds range in density from 12.3 to $15.3 \mathrm{ft}^{3} / \mathrm{t}$ and $14 \mathrm{ft}^{3} / \mathrm{t}$. The estimates of the full zone and of the shalephosphorite combination were based on a density of 14 $\mathrm{ft}^{3} / \mathrm{t}$; those of the shale bed alone were based on a density of $15.3 \mathrm{ft}^{3} / \mathrm{t}$.

\section{EXPERIMENTAL MINING AND PROCESSING}

The Wyodak Coal and Manufacturing Co. demonstrated in 1943 the feasibility of mining both the shale and phosphorite together and the full zone. The USBM (Ravitz and others, 1947) undertook preliminary studies of recovery processes. In the mid-1970's, Earth Sciences, Inc., did experimental mining in Bloomington Canyon and developed a plan for extracting the shale bed by augur mining. Mine production of 211,000 tons/yr was planned to yield, after roasting and leaching, 3,000,000 lb of $\mathrm{V}_{2} \mathrm{O}_{5}$ as ferrovanadium, $67,500 \mathrm{lb}$ of selenium, $33,900 \mathrm{lb}$ of $\mathrm{U}_{3} \mathrm{O}_{8}$, and 59,100 tons of phosphate concentrate containing 32 percent $\mathrm{P}_{2} \mathrm{O}_{5}$; molybdenum was recoverable, too, but in amounts too small to market (De Vota and Stevens, 1979). Cost analysis projected a 9.5 percent rate of return on investment. Although this rate was thought to be minimally adequate then, development did not follow; given the subsequent decline in commodity prices, it may be assumed that production is still not economically feasible.

\section{ORIGIN}

Many marine black shales contain concentrations of vanadium in the range of 0.2 to 0.35 percent $\mathrm{V}_{2} \mathrm{O}_{5}$ (for example, Davidson and Lakin, 1961; Vine, 1969; Vine and Tourtelot, 1970), and a few contain somewhat larger amounts (Krauskopf, 1955; Coveney and Martin, 1983; Poole and Desborough, 1985). They also commonly contain suites of trace metals similar to those of the vanadiferous zone of the Phosphoria Formation. None have been reported, however, in the range of 2.0 to 2.5 percent $\mathrm{V}_{2} \mathrm{O}_{5}$ found within the zone in western Wyoming or at the average of nearly 1 percent over an average thickness of about $10 \mathrm{ft}$ found in the ParisBloomington area of Idaho. Exceptional also is the total vanadium content of the Meade Peak Member. The member averages 0.02 to 0.1 percent $\mathrm{V}_{2} \mathrm{O}_{5}$ in southeastern Idaho and western Wyoming (fig. 3) (Maughan, 1976, 1980). All of its beds at Coal Canyon except one contain vanadium in amounts greater than the average crustal abundance, and 10 beds outside the vanadiferous zone contain it in the range of 0.2 to 0.42 percent $\mathrm{V}_{2} \mathrm{O}_{5}$ (McKelvey and others, 1953; Gulbrandsen, 1960).

The Meade Peak Member in general and its vanadiferous zone in particular, then, have exceptional concentrations of vanadium, although they are otherwise similar in trace-metal content to many other black shales. Their origins very likely are similar, but the higher concentration of $\mathrm{V}_{2} \mathrm{O}_{5}$ in the Meade Peak Member requires explanation. The vanadiferous zone is clearly the product of primary deposition from upwelling water in an anoxic marine environment below wave base in a water depth of 100 to $300 \mathrm{~m}$ or so. The deposits formed on a large embayment on the outer continental shelf on the western side of the North American craton at low latitude, where deep, cold, nutrient-rich seawater welled up as a result of divergent upwelling in a tradewind belt. The carbonaceous mudstones, of which the vanadiferous zone is a part, are the outer shelf facies equivalents of nearer shore phosphorite, chert, carbonate rock, redbeds, and evaporites. The carbonaceous, phosphatic, and cherty sediments are direct or indirect manifestations of the high biologic productivity characteristic of the shelf environment. Concentration of the vanadium and associated metals took place at about the same time as deposition or burial of the associated sediment, which accumulated very slowly in an environment of circulating seawater. 
The reasons for these conclusions are straightforward. The lateral continuity over thousands of square miles of thin beds of very fine grained sediment underlain and overlain by rocks containing marine fossils allows only syngenetic deposition in a marine environment. The abundant organic matter (part of which may be bituminous), pyrite, and other sulfides testify to accumulation under reducing conditions. The geographic setting of the Meade Peak Member, including its relation to upwelling, has been established by regional stratigraphic studies of the Phosphoria Formation (for example, McKelvey and others, 1959; Sheldon, 1964, 1981). The requisite slow deposition and circulating seawater are also necessary for phosphorite (McKelvey, 1946). The concentrations of vanadium in the zone are so high (locally, 150 times or more its crustal abundance of $150 \mathrm{~g} / \mathrm{t}$ ) (Rankama and Sahama, 1950) relative to its ordinary occurrence that they could have been attained only in the absence of the dilution that would have resulted from sedimentation at ordinary rates. Furthermore, the vanadium content of seawater $(2.5 \mathrm{ppb}$ (Brewer, 1975)) is so low that even the total extraction of the vanadium in a standing column of seawater several times the probable depth of the Meade Peak sea would not begin to equal the amount of vanadium found in the vanadiferous zone. ${ }^{2}$

Beyond these observations, the origin of the vanadiferous zone can be addressed only with questions and speculations. For example, how are vanadium and other metals held? What led to their precipitation from seawater? What factors are responsible for their exceptionally high concentration in both the vanadiferous zone and in the Meade Peak Member as a whole? What was the specific environment in which the high concentrations were localized?

As McKelvey (1946) discussed, the vanadium in the vanadiferous zone may occur as sulfide, as adsorbed ions on clay minerals, or contained in organic matter. Vanadium has been found in each of these forms in some sedimentary rocks (Rankama and Sahama, 1950). Some support for its presence in a clay or other silicate mineral came from R.A. Gulbrandsen (written communication, 1985), who tested a sample of the Coal Canyon vanadiferous zone in hydrochloric and hydrofluoric acids. He found that essentially no vanadium was dissolved by hydrochloric acid but that vanadium was dissolved by hydrofluoric acid. Since hydrofluoric acid dissolves silicate minerals, this result suggests

\footnotetext{
${ }^{2}$ For example, a water column $1 \mathrm{~m}^{2}$ and $1,000 \mathrm{~m}$ deep-10 times the probable depth of the Meade Peak sea-containing $2.5 \mathrm{pbb} \mathrm{V}$ (see table 16) would contain only $2.5 \mathrm{~g} \mathrm{~V}$. One square meter of the upper part of the vanadiferous zone in Sublette Ridge, averaging $0.686 \mathrm{~m}$ thick and 0.594 percent $\mathrm{V}$. contains $8,521 \mathrm{~g} \mathrm{~V}$, the equivalent of the vanadium in about 3,400 such water columns.
}

that vanadium occurs in one or more silicate minerals. Desborough's (1977) subsequent electron microprobe studies showed that vanadium is held in organic matter. The recent work of E.C.T. Chao, J.A. Minkin, and J.M. Back (written communication, 1986) confirmed both observations-that vanadium is within semifusinite but that some of it is attached to illite. ${ }^{3}$ According to George Breit (written communication, 1986), "...there seems to be a general progression in the form of vanadium in black shales. Soon after deposition the vanadium is tightly associated with organic fragments. In older units, especially those past the point of oil generation, the vanadium is tied up in clays and occasionally sulfides."

In what chemical form is the vanadium held by the organic matter? The richest bed of the vanadiferous zone in western Wyoming has a $\mathrm{V}_{2} \mathrm{O}_{5}$ content of 2 percent or more and an organic matter content of about 25 percent; thus, its $\mathrm{V}_{2} \mathrm{O}_{5}$ content would be 8 percent or more. Carbonaceous matter is known to be a good chemical adsorbent for metals, and bituminous shales that are high in vanadium and some other metals are relatively high in organic carbon (Desborough, 1977; Maughan, 1980; Holland, 1984). But many shales rich in organic carbon, including some in the Phosphoria Formation, have low trace-metal contents, so the correlation is not necessarily direct.

Bader (1937, cited by Rankama and Sahama, 1950, p. 599) believed that the vanadium in vanadiferous crude oils and bituminous shales is held in porphyrin complexes. A Persian crude oil has been reported to contain 2.82 percent $\mathrm{V}\left(5.03\right.$ percent $\left.\mathrm{V}_{2} \mathrm{O}_{5}\right)$, but the maximum vanadium content in most vanadiferous crudes, including the heavy crudes from which vanadium is recovered commercially, is of the order of $1,000 \mathrm{ppm}$ (Hunt, 1979). Bader's average vanadium content for asphalt is $5,400 \mathrm{ppm}$, although Fischer (1973) reported that many asphaltites contain about 1 percent. Recently, a vanadyl deoxophylloerythroetioporphyrin was extracted from an oil shale at Julia Creek in Queensland, Australia (Ekstrom and others, 1983; Miller and others, 1984). This oil shale, which contains as much as 0.5 percent $\mathrm{V}$, is in a micamontmorillonite clay; that part of the vanadium in organic matter is in kerogen (Riley and Saxby, 1982). Saoiabi and others (1983) also reported vanadyl and

\footnotetext{
${ }^{3}$ Semifusinite, which consists of carbonized woody tissue, is characteristically of terrestrial origin, but, because the environment of deposition of the vanadiferous zone was more than $125 \mathrm{mi}$ from the nearest land, where an arid climate probably prevailed, a terrestrial origin for it here seems dubious. The point of its origin is not important, however. As Chao recognized, its environment of deposition was marine, and it is clear that the living plants could not have acquired such large quantities of vanadium.
} 
nickel porphyrins from Moroccan oil shales. The vanadium content of these porphyrins is not known to us, but, if they were the vanadium analogue of the nickel porphyrin abelsonite $\left(\mathrm{C}_{31} \mathrm{H}_{32} \mathrm{~N}_{4} \mathrm{Ni}\right.$ ) (Milton and others, 1978), they would contain 17.85 percent $\mathrm{V}_{2} \mathrm{O}_{5}-$ just about the amount needed if half the organic matter in the highly vanadiferous beds were in that form.

Premovic and others (1986) also found $\mathrm{VO}_{2}^{+}$ porphyrins in the Triassic Serpiano marl of Switzerland and the Cretaceous La Luna shaly limestone of Venezuela, which contain about 2,700 and $1,100 \mathrm{ppm}$ $\mathrm{V}$, respectively. About half of the total vanadium in both formations is in kerogen, and the remainder is in the extractable organic, HCL-soluble, and HF-soluble fractions. The $\mathrm{VO}_{2}^{+}$porphyrins are in the extractable organic and kerogen fractions. In view of these occurrences and others reported by Premovic and others, it seems likely that at least some of the vanadium in the Meade Peak Member is in the form of porphyrins.

In addition to the phosphorite in the vanadiferous zone in the Paris-Bloomington area, several other phosphorites in the Meade Peak Member contain vanadium, generally in the range of 0.2 to 0.4 percent $\mathrm{V}_{2} \mathrm{O}_{5}$. In fact, vanadium is currently being recovered as a byproduct of the manufacture of elemental phosphorus in southeastern Idaho. Some of the vanadium in phosphorite probably occurs in carbonate fluorapatite in substitution for phosphorus (Rankama and Sahama, 1950; McConnell, 1953). Some of it, however, may also be held by organic matter (Krauskopf, 1955; Gulbrandsen, 1966).

Phosphorites also contain moderately high concentrations of the other metals found in the vanadiferous zone. Southeastern Idaho phosphorites, for example, average $90 \mathrm{ppm} \mathrm{Cd}, 800 \mathrm{ppm} \mathrm{Cr}, 85 \mathrm{ppm} \mathrm{Cu}, 30 \mathrm{ppm}$ $\mathrm{Mo}, 100 \mathrm{ppm} \mathrm{Ni}, 30 \mathrm{ppm}$ Se, $5 \mathrm{ppm} \mathrm{Ag,} 3 \mathrm{ppm}$ Th, and $250 \mathrm{ppm} \mathrm{Zn}$ (Gulbrandsen, 1977). These concentrations, for the most part, are much higher than those of the average phosphorite reported by Altschuler (1980)namely, $18 \mathrm{ppm} \mathrm{Cd}, 125 \mathrm{ppm} \mathrm{Cr}, 7 \mathrm{ppm} \mathrm{Cu}, 9 \mathrm{ppm} \mathrm{Mo}$, $53 \mathrm{ppm} \mathrm{Ni}, 4.6 \mathrm{ppm} \mathrm{Se,} 2 \mathrm{ppm} \mathrm{Ag}$, and $195 \mathrm{ppm} \mathrm{Zn.} \mathrm{No}$ gold determinations have been made for phosphorite in the Sublette Ridge or Paris-Bloomington areas, but $0.4 \mathrm{ppm} \mathrm{Au}$ has been found farther north in western Wyoming (Love, 1984).

According to Rankama and Sahama (1950), vanadium in upper oxygenated seawater is in the quinquevalent state. Reduction in oxygen-deficient bottom waters would lead to its precipitation in some form. Holland (1979) found that the concentrations of $\mathrm{Ag}$. $\mathrm{Cu}, \mathrm{Ni}, \mathrm{V}$, and $\mathrm{Zn}$ at the highest median value reported for 20 sets of black shales by Vine and Tourtelot (1970) represent a surprisingly narrow range of enrichment factors over their concentrations in seawater of 2.5 to $8 \times 10^{5}$ (table 17). Even at the highest 95th percentile in the same 20 sets of samples, the enrichment factor for these metals ranged only from 5 to $23 \times 10^{5}$. Noting the reported removal of such metals by precipitation from the anoxic part of the water column in the Black Sea (Brewer and Spencer, 1974), Holland (1979, p. 1679) concluded that, although "...many metals participate actively in biochemical cycles...the available data (see, for instance, Brewer, 1975) suggest that the concentration of trace metals in living organisms is not large enough to account for the observed enrichment of trace metals in black shales. Apparently, the concentration of metals in organic-rich sediments owes more to chemical precipitation and to reactions with dead organic remains than to their incorporation in living organisms" (see also Holland, 1984).

The common occurrence of these metals in bituminous shales deposited in the upwelling environment led Brongersma-Sanders (1969) to suggest that they are transported from surface to deeper water layers by organisms and concentrated there by resolution after death. Precipitation of the metals may take place if the decay of organic matter leads to deoxygenation of the bottom waters and the formation of $\mathrm{H}_{2} \dot{\mathrm{S}}$. She cited data given by Schutz and Turekian (1965) on Ag, Ni, and Co showing "...high concentrations in areas of high organic productivity (upwelling water) accompanied by an increase of concentration with depth" (Brongersma-Sanders, 1969, p. 234).

Thus, upwelling water itself may be important as a source of the metals. Bruland (1980) reported a marked increase in the content of $\mathrm{Zn}, \mathrm{Cd}, \mathrm{Ni}$, and $\mathrm{Cu}$ with depth in the central North Pacific; the increase for $\mathrm{Zn}$, $\mathrm{Cd}$, and $\mathrm{Ni}$ between the surface and a depth of 1.0 to 1.5 $\mathrm{km}$ is severalfold, a pattern almost identical to that long known for phosphate and nitrate (fig. 4). Cutter (1982) found that selenium also increases with depth and that it changes from selenate and selenite forms in the oxic zone to an organic selenide form in the anoxic zone. If, as seems likely, vanadium and the other characteristic trace metals of black shales follow the same pattern, upwelling would move metal-rich materials into the environment of deposition, just as it does for phosphate and the other major nutrient elements. ${ }^{4}$ Baturin (1982) confirmed the effectiveness

\footnotetext{
${ }^{4}$ Hite (1978) also considered a high metal source important, but he envisioned that source as a warm brine, enriched in phosphate as well as metals, refluxed to the sea from an evaporite basin and reacting with cold seawater. Perhaps the most problematic aspect of this novel hypothesis is the idea that the brine (presumably) retains its coherence as a sheet extending a few hundred miles seaward from its source, across bottoms where the fossil record shows sessile organisms lived, to the black shale environment.
} 
TABLE 17.-Some trace metals in seawater in comparison with their concentrations in black shales (Holland, 1979)

\begin{tabular}{|c|c|c|c|c|}
\hline $\begin{array}{l}\text { Seawater, } \\
\text { in ppb }\end{array}$ & $\begin{array}{l}\text { Highest median } \\
\text { of } 20 \text { sets } \\
\text { of black } \\
\text { shale samples. } \\
\text { in ppm } 1\end{array}$ & $\begin{array}{c}\text { Enrichment } \\
\text { factor over } \\
\text { seawater. } \\
\times 10^{5}\end{array}$ & $\begin{array}{l}\text { Highest } 95 \text { th } \\
\text { percentile } \\
\text { of } 20 \text { sets } \\
\text { of black } \\
\text { shale samples, } \\
\text { in ppm } 1\end{array}$ & $\begin{array}{c}\text { Enrichment } \\
\text { factor over } \\
\text { seawater. } \\
\times 10^{5}\end{array}$ \\
\hline $0.04^{2}$ & 10 & 2.5 & 20 & 5 \\
\hline $\mathrm{Cr}$ & 1,000 & 30 & 3,000 & 90 \\
\hline $\mathrm{Cu}$ & 200 & 8 & 500 & 20 \\
\hline $10.0^{2}$ & 300 & .3 & 700 & \\
\hline $\mathrm{Ni}$ & 500 & $8^{.0}$ & 1,000 & $16^{\cdot-1}$ \\
\hline $\mathrm{Pb}$ & 50 & 17 & 100 & 34 \\
\hline 2.5 & 1,000 & 4 & 2.000 & 8 \\
\hline (1) $-3.0^{1}$ & 1,500 & 5 & 7.000 & 23 \\
\hline
\end{tabular}

of upwelling in helping to concentrate the metals when he reported that diatomaceous ooze in the area of strong upwelling off southwestern Africa contains 455 ppm Ni, 337 ppm Zn, 129 ppm Cu, 500 ppm Mo, and $360 \mathrm{ppm} \mathrm{V}$, all fixed mainly in organic matter.

Although the metal content of organisms is generally very small, Z.A. Vinogradova and V.V.Koval'skiy (see Calvert, 1976) reported $200 \mathrm{ppm} \mathrm{Cu}$ and 2,600 ppm Zn in Black Sea plankton. Remarkable concentrations of vanadium occur in the blood of ascidians and holothurians. Rankama and Sahama (1950) reported an astonishing 10.4 percent $\mathrm{V}\left(18.6\right.$ percent $\left.\mathrm{V}_{2} \mathrm{O}_{5}\right)$ in holothurian blood (dry weight) - again, just about the right concentration needed if roughly half of the organic matter in the richly vanadiferous beds were in such a form. The idea that a significant part of the organic matter in the vanadiferous zone might be derived from holothurian blood is too bizarre to discuss further, but it does seem possible (even likely) that organisms played some part in extracting vanadium and other metals from seawater, similar to the role that has long been postulated for them in concentrating phosphate (see Gulbrandsen's (1969) review). Addressing the similar assemblage of metals found in phosphorites, Prevot and Lucas (1980) suggested that organisms bring these elements together and that the first trap for these elements is biologic. Subsequent steps in their concentration are accomplished by both biochemical and inorganic chemical processes.

As we indicated previously, it is possible that vanadium and some other metals are in the form of a porphyrin. Determination of the crystal structure of the vanadyl porphyrin from Australia is regarded as confirmation of the hypothesis that this porphyrin is a degradation product of chlorophyll (Ekstrom and others, 1983). But, although this hypothesis in turn may be taken as proof of the biologic origin of crude oil, it is also proof that the vanadium, replacing the magnesium of chlorophyll, was not sited in the porphyrin by a primary biologic process. Premovic and others (1986) reached a similar conclusion with respect to the Serpiano marl and the La Luna shaly limestone.

Are organisms the common denominator that brings the black shale metals (here taken to be $\mathrm{Ag}, \mathrm{Cd}, \mathrm{Cr}$, Mo, Ni, Se, Ti, U, V, and Zn) together, as Prevot and Lucas suggested? According to Bowen (1966), only Mo, $\mathrm{Se}, \mathrm{V}$, and $\mathrm{Zn}$ are essential to the life of some or all organisms. $\mathrm{Cr}$ and $\mathrm{Ni}$ may have an essential role, and $\mathrm{Cd}$ is known to be involved in a special biologic process. No biologic role has been reported for $\mathrm{Ag}, \mathrm{Ti}$, or $\mathrm{U}$. Three other metals that are also essential to life $(\mathrm{Co}$, $\mathrm{Cu}$, and $\mathrm{Mn}$ ) are present in black shales in low concentrations only. All of the black shale metals are known to be moderately to highly toxic to organisms in more than trace amounts. It thus seems unlikely that biologic necessity brings all of these metals together, particularly in the high concentrations in which they are found in the black shales. However, even though a biologic role is unknown for $\mathrm{Ag}$ and is limited or uncertain for $\mathrm{Cd}, \mathrm{Cr}$, and $\mathrm{Ni}$, all four elements are known to occur in both marine plants and animals, and all the black shale metals are known to occur in seawater. It is possible, therefore, that, even though some metals do not play a biologic role, they might be carried to the bottom in small concentrations in living or dead organic tissue.

Organic matter has been shown to be effective in adsorbing metals from seawater (Krauskopf, 1955). 

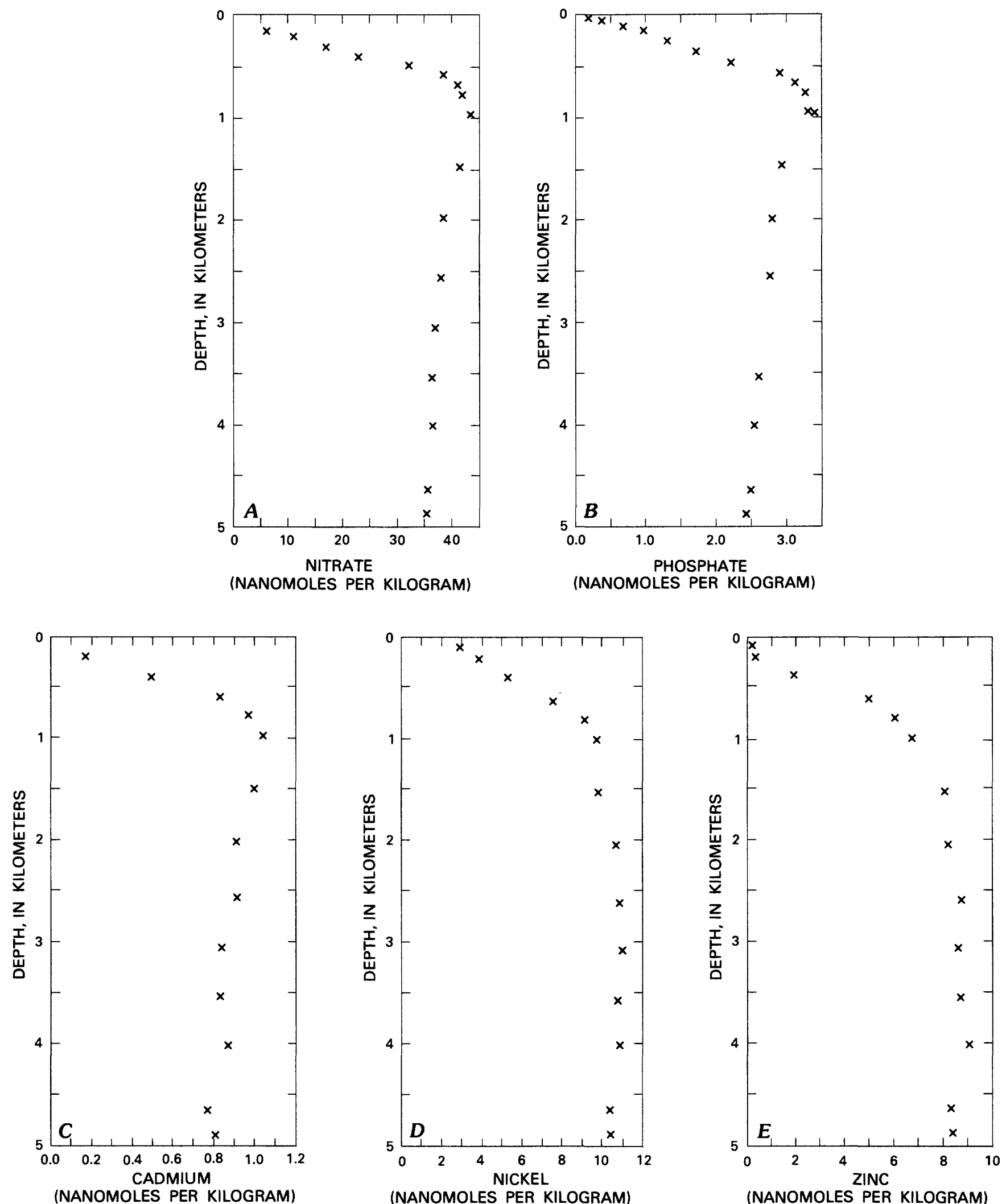

Figure 4.-Variation of $(A)$ nitrate, $(B)$ phosphate, $(C) \mathrm{Cd},(D) \mathrm{Ni}$, and $(E) \mathrm{Zn}$ in seawater with depth in the North Pacific Ocean at $32^{\circ} 41.0^{\prime} \mathrm{N}$., $144^{\circ} 59.5^{\prime} \mathrm{W}$. (drawn from Bruland, 1980). 
All things considered, the rough correlation between metal content and amount of organic carbon noted by other authors (for example, Maughan, 1976, 1980, 1984; Desborough, 1977) for metalliferous black shales does not seem to indicate that a biologic process is directly responsible for the deposition of the metals but rather shows the importance of organic matter in progressively concentrating the metals. Organisms withdraw small quantities of them, perhaps using them as nutrients, and these metals are then carried in dead tissue to the bottom, where they may be dissolved to add to their concentrations in bottom or interstitial water. Decaying organic matter creates the reducing conditions necessary for the fixation of vanadium and other metals and forms a site favorable for the fixation of some. As time passes, vanadium may move from organic matter to illite or other minerals (George Breit, written communication, 1986). The importance of an anoxic environment to the precipitation of the metals is worth stressing, since one thing that they all have in common is that their precipitation is favored by reducing conditions.

In summary, it seems reasonable to assume that the concatenation of such processes, combined with the slow accumulation of sediment, may account for the occurrence of vanadium and several other metals in the Meade Peak Member and in some other black shales. But the extraordinary concentrations of vanadium in the richest part of the vanadiferous zone (an order of magnitude higher than the ordinary black shale highs) seem to require conditions or processes not yet identified. The increase and subsequent decrease in the vanadium content from the base to the top of the zone over an area of several hundreds of square miles in western Wyoming (see, for example, pl. 2) imply a gradual buildup and then decline in one or more favorable environmental conditions, which cannot be defined with certainty. One possibility is that the principal variable was sediment accumulation rate, which increased and then decreased the time available for the resolution of vanadium from decaying organic tissue and for its withdrawal from circulating seawater. That variable alone, of course, would not account for the variation in the distribution of high concentrations of other metals within the vanadiferous zone.

Although the specifics of the environment in which the high concentrations of vanadium and other metals were deposited cannot yet be identified, the factors controlling the deposition of vanadium are independent of those controlling the deposition of phosphate, uranium, and carbonate, which increase westward from Wyoming to southeastern Idaho without appreciable change in the vanadium content of the zone. Such an increase would be expected if the redox potential (Eh) were the controlling factor in the deposition of vanadium and if hydrogen ion concentration $(\mathrm{pH})$, temperature, and $\mathrm{CO}_{2}$ content controlled the precipitation of apatite (which hosts the uranium) or carbonate, for those factors do not necessarily vary in concert. Although the deposition of V, P, U, and carbonate may take place simultaneously, the maximum concentration of vanadium and most other metals is favored by a $\mathrm{pH}$ and temperature low enough to prevent or retard accumulation of diluting phosphate or carbonate. Apatite, for example, is unstable below a $\mathrm{pH}$ of about 7.0 , and carbonate is unstable below a $\mathrm{pH}$ of about 7.5 (Gulbrandsen, 1969; Bentor, 1980). Apatite in modern sediments precipitates where the dissolved oxygen in bottom waters is lowest, probably owing to increased preservation of organic phosphorus rather than to an Eh control over the precipitation of apatite (Burnett and others, 1980).

Although other metals have been treated here as a group along with vanadium, their distribution within the zone does not conform exactly to that of vanadium, nor does it in other black shales. For example, in a group of 18 samples of black shales from the Pennsylvanian Mecca Quarry and Logan Quarry of Illinois and Indiana, analyzed by Coveney and Martin (1983), only the high value of zinc $(14,300 \mathrm{ppm})$ and total organic matter ( 46.5 percent) corresponded with the high vanadium value $(10,100 \mathrm{ppm})$. High $\mathrm{U}(240 \mathrm{ppm})$ and $\mathrm{Mo}(1,600 \mathrm{ppm})$ values were in another sample, and high values of $\mathrm{Pb}, \mathrm{Se}, \mathrm{Cu}$, and $\mathrm{Ni}(500,400,500$, and $1,300 \mathrm{ppm}$, respectively) were each in other samples. According to Disnar (1981), the capacity for organic matter to fix $\mathrm{U}, \mathrm{Cu}, \mathrm{Pb}, \mathrm{Zn}$, and $\mathrm{Ni}$ increases with increasing $\mathrm{pH}$, but, for Mo and $\mathrm{V}$, it increases with decreasing $\mathrm{pH}$; both groups of metals might be fixed coevally in the intermediate $\mathrm{pH}$ range. The divergence in the metal concentrations expected from these relations is not seen in either the Meade Peak or the Mecca-Logan samples, but it seems likely that the differences in the distribution of the metals do reflect differences in their behavior under varying $\mathrm{Eh}, \mathrm{pH}$, temperature, and perhaps other chemical conditions.

The exceptionally high concentrations of vanadium and other metals throughout the Meade Peak Member also deserve explanation. Perhaps these concentrations are merely the result of a long continued strong upwelling environment. An enriching factor, however, might have been volcanic ash, the presence of which is shown by the occurrence of buddingtonite (the ammonium feldspar) in most of the Meade Peak mudstones. According to Gulbrandsen $(1974$, p. 697), its "...distribution and concentrations...seem to show that great airfalls did not occur, but that small falls were 
frequent for a long period of time...." Buddingtonite is formed by the alteration of volcanic glass in an ammonia-rich environment, probably beneath the sediment-seawater interface. Its alteration conceivably might have released metals, which added to the amounts derived from seawater. Premovic and others (1986) favored volcanic ash as the source of vanadium in the Serpiano and La Luna rocks.

\section{CONCLUSIONS}

The vanadiferous zone of the Meade Peak Member in the Sublette Ridge area of Wyoming and the ParisBloomington area of Idaho contains about 5.9 million tons of indicated subeconomic resources averaging about 0.9 percent $\mathrm{V}_{2} \mathrm{O}_{5}$. Indicated resources in the Afton area of Wyoming area above drainage level total about 35 million tons of the same quality (Love, 1961). Inferred resources in western Wyoming and southeastern Idaho of about the same tenor are many times larger. The zone also contains $\mathrm{Cd}, \mathrm{Cr}, \mathrm{Mo}, \mathrm{Ni}, \mathrm{Se}, \mathrm{Ag}$, $\mathrm{Th}, \mathrm{Zn}$, and (in the Paris-Bloomington area) $\mathrm{U}$ in amounts many times their average crustal abundance.

Although the feasibility of mining these deposits has been shown by the Wyodak Coal and Manufacturing Co. and Earth Sciences, Inc., the feasibility of recovering vanadium commercially remains to be demonstrated. When the need for vanadium is reflected in increased prices, however, processes for its extraction will be explored again, under the justifiable expectation that economic production will be possible one day. The initial output probably will not be largethe production planned by Earth Sciences, Inc., would have supplied only 8.5 percent of national vanadium demand-but Meade Peak resources could eventually be a more important source of vanadium and several other metals.

\section{ACKNOWLEDGMENTS}

We are grateful to E.C.T. Chao, J.A. Minkin, and J.M. Back for their electron microprobe studies of the vanadiferous shale. We also thank George Breit, George Ericksen, Michael Fleischer, R.A. Gulbrandsen, H.D. Holland, and E.K. Maughan for their helpful suggestions. Gertrude A. Sinnott kindly assisted in obtaining references. We also thank Kathie R. Fraser for her fine work in editing the manuscript.

\section{REFERENCES CITED}

Allsman, P.T., Majors, F.Z., Mahoney, S.R., and Young, W.A., 1949a, Investigation of Sublette Ridge vanadium deposit, Lincoln
County, Wyo.: U.S. Bureau of Mines Report of Investigations 4476 .

-1949b, Investigation of Salt River Range vanadium deposit, Lincoln County, Wyo.: U.S. Bureau of Mines Report of Investigations $4503,18 \mathrm{p}$.

Altschuler, Z.S., 1980, The geochemistry of trace elements in marine phosphorites, pt. I, Characteristic abundance and enrichment, in Bentor, Y.K., ed., Marine phos phorites-Geochemistry, occurrence, genesis: Society of Economic Paleontologists and Mineralogists Special Publication 29, p.19-30.

Armstrong, F.C., and Cressman, E.R., 1963, The Bannock thrust zone, southeastern Idaho: U.S. Geological Survey Professional Paper 374-J, p. J1-J22.

Bader, E., 1937, Vanadin in organogenen Sedimenten, I, Die Gründe der Vanadinanreicherung in organogenen Sedimenten: Zentralblatt für Mineralogie, Geologie, und Paläontologie, Abt. A, p. 164.

Baturin, G.N., 1982, Phosphorites on the sea floor: New York, Elsevier, $343 \mathrm{p}$.

Bentor, Y.K., 1980, Phosphorites-The unsolved problems, in Bentor, Y.K. ed., Marine phosphorites-Geochemistry, occurrence, genesis: Society of Economic Paleontologists and Mineralogists Special Publication 29, p. 3-18

Bowen, H.S.M., 1966, Trace elements in biochemistry: New York, Academic, $241 \mathrm{p}$.

Boyle, E., Sclater, F.R., and Edmond, J.M., 1977, The distribution of dissolved copper in the Pacific: Earth and Planetary Science Letters, v. 37, p. 38-54.

Brewer, P.G., 1975, Minor elements in seawater, in Riley, J.P., and Skirrow, G., eds., Chemical oceanography, 2d ed.: New York, Academic, p. 415-496.

Brewer, P.G., and Spencer, D.W., 1974, Distribution of some trace elements in the Black Sea and their flux between dissolved and particulate phases: American Association of Petroleum Geologists Memoir 20, p. 137-143.

Brongersma-Sanders, M., 1969, Origin of trace metal enrichment in bituminous shales, in Hobson, G.D., and Speers, C.C., eds., Advances in organic geochemistry, Third International Congress Proceedings: Oxford, Pergamon, p. 231-236.

Bruland, K.W., 1980, Oceanographic distribution of cadmium, zinc, nickel and copper in the North Pacific: Earth and Planetary Science Letters, v. 47, p. 176-198.

Burnett, W.C., Veeh, H.H., and Soutar, A., 1980, U-series, oceanographic and sedimentary evidence in support of Recent formation of phosphate nodules off Peru, in Bentor, Y.K., ed., Marine phosphorites-Geochemistry, occurrence, genesis: Society of Economic Paleontologists and Mineralogists Special Publication 29, p. 61-72.

Calvert. S.E., 1976, The mineralogy and geochemistry of nearshore sediments, in Riley, J.P., and Chester, R., eds., Chemical oceanography, v. 6: New York, Academic, p. 187-280.

Coveney, R.M., Jr., and Martin, S.P., 1983, Molybdenum and other heavy metals of the Mecca Quarry and Logan Quarry shales: Economic Geology, v. 78, p. 132-149.

Cutter, G.A., 1982, Selenium in reducing waters: Science, v. 217, p. 829-831.

Davidson, D.F., and Lakin, H.W., 1961, Metal content of some black shales of the Western United States: U.S. Geological Survey Professional Paper 424-C, p. C329-C331.

Desborough, G.A. 1977, Preliminary report on certain metals of potential economic interest in thin vanadium-rich zones in the Meade Peak Member of the Phosphoria Formation in western Wyoming and eastern Idaho: U.S. Geological Survey Open-File Report 77-341, $27 \mathrm{p}$. 
De Voto, R.H., and Stevens, D.N., 1979, Uraniferous phosphate resources and technology and economics of uranium recovery from phosphate resources, United States and free world: U.S. Department of Energy Report GJBX-79, $3 \mathrm{v}$.

Disnar, J. R., 1981, Etude experimental de la fixation de metaux par un material sedimentaire actuel d'origine algaire, II, Fixation 'in vitro' de $\mathrm{UO}_{2}{ }^{2+}, \mathrm{Ni}^{2+}, \mathrm{Zn}^{2+}, \mathrm{Pb}^{2+}, \mathrm{Co}^{2+}, \mathrm{Mn}^{2-}$, ainsi que dt $\mathrm{VO}_{3}-\mathrm{Mo}_{4}{ }^{2-}, \mathrm{GeO}_{3}{ }^{2-}$ : Geochimica et Cosmochimica Acta, v. 45, p 363-379.

Ekstrom, A., Fookes, C.J.R., Hambley, T., Locke, H.J., Miller, S.A., and Taylor, J.C., 1983, Determination of the crystal structure of a petrophyrin isolated from oil shale: Nature, v. 306, p. 173-174.

Fischer, R.P., 1973, Vanadium: U.S. Geological Survey Professional Paper 820, p. 679-688.

Gulbrandsen. R.A., 1960, Petrology of the Meade Peak phosphatic shale member of the Phosphoria Formation at Coal Canyon, Wyoming: U.S. Geological Survey Bulletin 1111-C, 146 p.

1975. Analytical data on the Phosphoria Formation, Western United States: U.S. Geological Survey Open-File Report 75-554, $45 \mathrm{p}$.

- 1966. Chemical composition of phosphorites of the Phosphoria For mation: Geochimica et Cosmochimica Acta, v. 30, p. 769-778.

- 1969, Physical and chemical factors in the formation of marine apatite: Economic Geology, v. 64, p. 365-382.

1974, Buddingtonite, ammonium feldspar, in the Phosphoria Formation, southeastern Idaho: U.S. Geological Survey Journal of Research, v. 2, p. 693-697.

1977, Final environmental impact statement, v. 1, Development of phosphate resources in southeastern Idaho: Washington, D.C.. U.S. Department of the Interior and U.S. Department of Agriculture, p. 1-53.

Hite, R.J., 1978, Possible genetic relationships between evaporites, phosphorites, and iron-rich sediments: The Mountain Geologist, v. 14 , no. 3 , p. $97-107$.

Holland, H.D., 1979, Metals in black shales-A reassessment: Economic Geology, v. 74. p. 1676-1680.

1984, The chemical evolution of the atmosphere and the oceans: Princeton, N.J., Princeton University Press, 582 p.

Hunt, J.M., 1979, Geochemistry and geology of petroleum: San Francisco, Freeman, 619 p.

Krauskopf, K.B., 1955, Sedimentary deposits of rare metals: Economic Geology 50th anniversary volume, pt. 1, p. 411-463.

'Lotspeich, F.O., and Marquard, E.L., 1963, Minor elements in bedrock, soil, and vegetation at an outcrop of the Phosphoria Formation on Snowdrift Mountain in southeastern Idaho: U.S. Geological Survey Bulletin 1181-F, 42 p.

Love, J.D., 1961, Vanadium and associated elements in the Phosphoria Formation in the Afton area. western Wyoming: U.S Geological Survey Professional Paper 424-C. p. C279- C282.

1984, Gold, silver, and other selected trace elements in the Phosphoria Formation of western Wyoming: Wyoming Geological Association Annual Field Conference, 35th. Casper. Wyo., 1984. Guidebook, p. 383-387

Manheim, F.T.,and Gulbrandsen, R.A., 1979, Marine phosphorites. in Burns, R.G., ed., Marine minerals: Mineralogical Society of America Short Course Notes, v. 6, p. 151-170.

Maughan, E.K., 1976, Organic carbon and selected element distribution in the phosphatic shale members of the Permian Phosphoria Formation, eastern Idaho and parts of adjacent States: U.S. Geological Survey Open-File Report 76-577, 92 p.

- 1980, Relation of phosphorite, organic carbon, and hydrocarbons in the Permian Phosphoria Formation. Western United States of A merica: Bureau de Recherches Geologiques et Minieres Document 24, p. 63-91.
- 1984, Geological setting and some geochemistry of petroleum source rocks in the Permian Phosphoria Formation, in Woodward, J., Meissner, F.F., and Clayton, J., eds., Hydrocarbon source rocks of the greater Rocky Mountain region: Denver, Colo., Rocky Mountain Association of Geologists, p. 281-294.

MeConnell, D., 1953, Radioactivity of phosphatic sediments: Economic Geology, v. 48, p. 147-148.

Mc Kelvey, V.E., 1946, Preliminary report on the stratigraphy of the phosphatic shale member of the Phosphoria Formation in western Wyoming, southeastern Idaho, and northern Utah: U.S. Geological Survey Open-File Report, 138 p.

Mc Kelvey, V.E., and Strobell, J.D. Jr., 1955, Preliminary geologic maps of the Paris-Bloomington vanadium area, Bear Lake County, Idaho: U.S. Geological Survey Miscellaneous Field Studies Map MF-41, scales 1:12,000 and 1:4,800.

McKelvey, V.E., Smith, L.E., Hoppin, R.A., and Armstrong, F.C., 1953, Stratigraphic sections of the Phosphoria Formation in Wyoming, 1947-1948: U.S. Geological Circular 210, 33 p.

McKelvey, V.E., and others, 1959, The Phosphoria, Park City, and Shedhorn Formations in the western phosphate field: U.S. Geological Survey Professional Paper 313-A, 17 p.

Miller, S.A., Hambley, T.W., and Taylor, J.C., 1984, Crystal and molecular structure of a natural vanadyl porphyrin: Australian Journal of Chemistry, v. 37, p. 761-766.

Milton, C., Dwornik, E.J., Estep-Barnes, P.A., Finkelman, R.B., Pabst, A., and Palmer, S., 1978, Abelsonite, nickel porphyrin, a new mineral from the Green River Formation, Utah: American Mineralogist, v. 63, p. 930-937.

Poole, F.G., and Desborough, G.A., 1985, Metal concentrations in marine black shales: U.S. Geological Survey Circular 949, p. 43-44.

Premovic, P.I., Pavlovic, M.S., and Pavlovic, N.Z., 1986, Vanadium in ancient sedimentary rocks of marine origin: Geochimica et Cosmochimica Acta, v. 50, p. 1923-1931.

Prevot, L., and Lucas, J., 1980, Behavior of some trace elements in phosphatic sedmentary formations, in Bentor, Y.K., ed., Marine phosphorites-Geochemistry, occurrence, genesis: Society of Economic Paleontologists and Mineralogists Special Publication 29. p. 31-40.

Rankama, K., and Sahama, T.G., 1950, Geochemistry: Chicago, University of Chicago Press, 912 p.

Ravitz, S.F., Nicholson, I.W., Chindgren, C.J., Bauerle, L.G., Williams, F.P., and Martinson, M.T., 1947, Treatment of IdahoWyoming vanadiferous shales: American Institute of Mining Engineers Technical Publication 2178, $14 \mathrm{p}$.

Riley, K.W.. and Saxby, J.D., 1982, Association of organic matter and vanadium in oil shale from the Toolebec Formation of the Erhomang Basin, Australia: Chemical Geology, v. 37, p. 265-275.

Rowe, J.J.. and Steinnes, E., 1976, Determination of rhenium in sedimentary rocks by instrumental activation analysis using epithermal neutrons: Radiochemistry and Radioanalysis Letters, v. 26, p. 324 .

Rubey. W.W., 1943, Vanadiferous shale in the Phosphoria Formation, Wyoming and Idaho [abs.]: Economic Geology, v. 38, p. 87. 1958, Bedford. Wyo.. geology: U.S. Geological Survey Geologic Quadrangle Map GQ-109, scale 1:62,500.

Saoiabi, A., Ferhat, M., Barbe, J.M., and Guilard, R., 1983, Metals, including vanadyl and nickel porphyrins, in the oil shales of Timahdit, Morocco: Fuel, v. 62, p. 963-965.

Schutz, D.F., and Turekian, K.K.. 1965, The investigation of the geographical and vertical distribution of several trace elements in sea water using neutron activation analysis: Geochimica et Cosmochimica Acta, v. 29, p. 259-313. 
Sclater, F.R., Boyle, E., and Edmond, J.M., 1976, On the marine geochemistry of nickel: Earth and Planetary Science Letters, v. 31 , p. 119-128.

Sheldon, R.P., 1964, Paleolatitudinal and paleogeographic distribution of phosphorite: U.S. Geological Survey Professional Paper 501-C, p. C106-C113.

1981, Ancient marine phosphorites: Annual Review of Earth and Planetary Science, v. 9, p. 251-284.

Vine, J.D., 1969, Element distribution in some Paleozoic black shales and associated rocks: U.S. Geological Survey Bulletin 1214-B, $32 \mathrm{p}$.

Vine, J.D., and Tourtelot, E.B., 1970, Geochemistry of black shale deposits-A summary report: Economic Geology, v. 65, p. 253-272. 